This is a self-archived - parallel published version of this article in the publication archive of the University of Vaasa. It might differ from the original.

\title{
Contracts as Interfaces
}

Author(s): Haapio, Helena; Passera, Stefania

Title: $\quad$ Contracts as Interfaces

Year: $\quad 2021$

Version: Accepted manuscript

Copyright (C) Cambridge University Press 2021. This material has been published in Legal Informatics edited by Katz, D. M., Dolin, R. \& Bommarito, M. J. (Editors), https://doi.org/10.1017/9781316529683. This version is free to view and download for private research and study only. Not for re-distribution or re-use.

Please cite the original version:

Haapio, H. \& Passera, S. (2021). Contracts as Interfaces. In: Katz, D. M., Dolin, R. \& Bommarito, M. J. (Eds.) Legal Informatics, 213-238. Cambridge: Cambridge University Press. https://doi.org/10.1017/9781316529683.018 


\title{
Contracts as interfaces:
}

\section{exploring visual representation patterns in contract design}

\author{
Helena Haapio \& Stefania Passera
}

\section{Introduction}

The world of contracting is undergoing fundamental changes. This is partly due to technology, but not entirely: while there can be tremendous benefits from self-enforcing, machine-readable contracts, these do not work everywhere. Many contracts still continue to be performed by people. In the context of this chapter, commercial deals and relationships, ${ }^{1}$ a vast number of contracts still need to be planned, understood, approved, implemented, and monitored by people. Initiatives world-wide seek to innovate contracting processes and documents and develop more effective, engaging ways for people to work with them. This chapter focuses on these initiatives and the need to make contracts truly human-readable.

From this perspective, we argue that today's contracts do not work as well as they should. Surveys by the International Association for Contract and Commercial Management (IACCM, $2015 \mathrm{a} ; 2015 \mathrm{~b}$ ) reveal that the vast majority of business people find contracts hard to read or understand and that current contracts are of little practical use to delivery teams and project managers. When it comes to usability and user experience, contracts are well below the standard people have come to expect from anything else they work with. In terms of style, contracts do not support cognitively-overloaded, busy readers in searching, integrating, and understanding the information they contain (Passera, Kankaanranta \& Louhiala-Salminen, forthcoming). In terms of content, contracts are written with litigation in mind, rather than day-to-day business support. The focus is on creating legally enforceable promises and causes of claims against the other party, rather than on helping both parties to deliver on their promises.

\footnotetext{
${ }^{1}$ This chapter focuses on business-to-business (B2B) contracts that anticipate ongoing relationships over time. Apart from some examples in Section 6, it does not address consumer contracts or public procurement contracts. Still, many of the issues discussed here may also apply to such contracts. In B2B contracting, the parties' freedom of contract is at its widest. Legislators have taken steps to promote the writing of consumer contracts in plain language, to protect consumers from making contracts they do not understand, and to help consumers to better know their rights and duties under those contracts. But see Williams 2011, 144: "the results are not always as spectacular as one might wish", and Id., 146: "the general situation is that contracts still tend to be plagued with old-fashioned forms of legalese".
} 
While contracts can serve as a means to sanction breach and provide a winning argument in court, we believe that they should not be seen "primarily as a source of trouble and disputation". 2 This is a fundamental premise of the work of Louis M. Brown $(1950,3)$, known as the Father of Preventive Law. While in curative law it is essential for lawyers to predict what a court will do, in Preventive Law it is essential to predict what people will do. People are the focus of this chapter: those in charge of planning, negotiating, implementing or monitoring contracts, such as, for example, proposal, contract, commercial, sales, procurement, and project managers. Building on what is known as the Proactive/Preventive Law (PPL) ${ }^{3}$ approach and on insights from the field of information design, ${ }^{4}$ our work is geared towards helping people use contracts to achieve their business goals and prevent unnecessary problems.

It follows that, in order to work well, contracts can no longer simply be drafted by lawyers for lawyers. Instead, we argue that the concept of contract drafting should be replaced by that of contract design, where strategic choices about the drivers and goals of collaboration merge with business and legal knowledge about how to maximize the chances of success and minimize risks and disputes, all wrapped up in people-centered communications to ensure that the contract can actually be implemented within the allotted time, with the resources that have been allocated, and within budget.

Contract design is not only a matter of selecting the right content, words or clauses. It is also a matter of making sure the message is understood. In this chapter, we concentrate on the communicative aspects of contracts, in particular on the relatively new stream of research and practice that proposes visual communication as a way to enhance contract clarity and ease of use (e.g., Haapio 2013a; 2013b; IACCM 20165\% Passera \& Haapio, 2011). To understand the diverse visual practices and approaches in this emerging field, we propose a categorization based on design patterns. Patterns can be defined as reusable models of a solution to frequently occurring

\footnotetext{
${ }^{2}$ According to Macneil and Gudel (2001, vii-viii), “[o]nly lawyers and other trouble-oriented folk look on contracts primarily as a source of trouble and disputation, rather than a way of getting things done."

${ }^{3}$ Traditionally, the focus in the legal field has been on the past, mainly on failures and how to react to them through legal proceedings, remedies, sanctions, punishment, fines, and so on. Preventive Law promotes a different approach: one where the focus is on the future and on using the law and legal skills to prevent disputes and eliminate causes of problems (Barton, 2007). Proactive Law adds a focus to achieving positive goals and value. Together, PPL can harness tools toward smoother operations and successful outcomes (Haapio \& Barton, forthcoming).

${ }^{4}$ Information design is a discipline concerned with displaying information in ways that support effective and efficient understanding by the intended audience, in the expected context of use.

${ }^{5}$ The IACCM Contract Design Award Program and the IACCM Contract Design Assessment Program promote the creation of clear and easy to use contracts and the use of contract visualization; see www.iaccm.com/iaccm-awards and www.iaccm.com/iaccm-assessments.
} 
problems in a domain (Haapio \& Hagan, 2016). Each pattern solves a specific problem, as different tools in a toolbox have unique functions. While the exact implementation of a pattern may vary, each pattern will retain distinguishing features that allow us to recognize and re-create it (Khambete, 2011). Framing visualizations as patterns helps to avoid an overly prescriptive approach to contract design, of which we are wary. For us, designing contracts means making strategic choices which are always highly contextual. What constitutes a "good" solution will depend on the users' characteristics (e.g., literacy levels), information needs and goals (e.g., what they need to know to perform their job), and overall business strategy (e.g., whether the transaction or relationship is short- or long-term).

Our particular focus is on visual representations such as diagrams and icons which can be used to explain and disambiguate contract text, complementing rather than substituting for it. These patterns can be used in actual contracts, contract briefs, or guidance, and as thinking tools during negotiations. Following the design pattern approach, we describe the benefits of these visual solutions by illustrating the problems they address. Each pattern is explained through actual examples encountered in our research and practice.

Our approach may seem rather handcrafted and non-computational to legal informatics scholars and practitioners. However, we need to recognize that our brains are actually information processing systems that should not be forgotten in the pursuit of the exciting possibilities of technology. In a socio-technical system comprised of people, computers, and business/legal information, we need to ensure that people do not become the weak link. For instance, while a contract can easily be automatically assembled by dedicated software relying on clause libraries, those clauses still need to be of good quality and, in our context, intelligible to end users. Our approach is a useful complement to the field, as it helps to address the problem of "garbage in, garbage out". In addition, the process of visualizing can help contract authors to plan, clarify and test the logical correctness of the text they create (Australian Office of Parliamentary Counsel, 2013; Berman, 2000). Visual design patterns can then be used to present the content in simpler, more transparent ways to contract users.

The following chapter is structured as follows: firstly, we address some unwarranted assumptions about the purpose and functions of contracts. We then propose the need for new, people-centered approaches, focusing on the paradigm shift from contract drafting to contract design as envisioned in PPL. We introduce the concept of design patterns, repeatable best 
practice solutions to communication problems in contracts. We go on to examine three families of contract visualization patterns that can be used to make contracts more readable, understandable, and engaging. Finally, we show examples of six kinds of visual representations which, we believe, offer repeatable solutions to recurring contract communication problems.

\section{The challenge: dysfunctional contracts and the need for a paradigm shift}

The evidence that current contracts do not work well comes from both research and practice. The IACCM's Attitudes to Contracting study reveals that weaknesses in contract terms and negotiations are a frequent cause of cost overruns and project delays. The use of traditional, legally-driven forms renders most contracts of little practical use to delivery teams and project managers, undermining their primary value as instruments of communication and understanding (IACCM, 2015a, 1). More than 90 percent of business people find contracts hard to read or understand, with the result that users see contracts as irrelevant to business needs; furthermore, in more than 90 percent of organizations, contracts are viewed primarily as instruments for control and compliance rather than business enablers and tools for improved communication and understanding (IACCM, 2015b, 6).

One reason for these findings is that lawyers have monopolized contract drafting, even in countries where there are no regulatory requirements to support it. As a result, contracts look like legal documents, not business documents. Their look and feel reinforces the view of contracts as purely legal tools, something to be left to lawyers (Haapio \& Barton, forthcoming). When it comes to content, lawyer-drafters pay more attention to legal functionality than business functionality. Their aim is to draft content in a way that it is precise, accurate, unambiguous, enforceable, legally binding, and interpreted in a way that favors the party drafting it. Legal drafting anticipates hostile readers reading the document through the eyes of bad faith (e.g., Haapio, 2013, 50; Jacobson, 2008, 80; Mellinkoff, 1982, 15). ${ }^{6}$ IACCM's Top Negotiated Terms confirms that, year after year, negotiators continue to focus on terms that deal with the consequences of failure and neglect the terms that are most important for guiding the relationship (IACCM, 2015c).

\footnotetext{
${ }^{6}$ Cf. Mellinkoff in Legal Writing: Sense \& Nonsense (1982, 15): "Some day someone will read what you have written, trying to find something wrong with it. This is the special burden of legal writing, and the special incentive to be as precise as you can."
} 
Also, the backbone of a contract is rarely drafted from scratch. Since any given business deal resembles previous deals, most law firms and corporate legal departments see (re)using templates and clause libraries as the most efficient way to prepare new contracts. Despite the benefits, however, there is a downside: if archaic language and style is used in the original, repeating and automating those templates easily becomes "an exercise in garbage in, garbage out" (Adams, 2008; Adams \& Allen, 2012). Whether the process is based on copy-and-pasting or automation, contracts are compiled using templates put together by lawyers driven by the goal of minimizing legal risk in court, often at the cost of clarity and understanding (Haapio, 2013b, 50). Echoing the title of a book chapter by Malhotra (2012), we can see that using such templates means that even a great deal may end up with a terrible contract. So how do we move beyond this vicious circle?

When contract drafters imagine courtroom settings, their attention is on whether the language would prevail in court if its meaning were disputed by other lawyers; the needs of delivery teams and project managers, who need documents they can work with and act upon easily, are ignored (Haapio \& Barton, forthcoming). When this happens, contract implementers may create their own translations of the contract, thus widening the gap between what Macaulay (2003) calls the "paper deal" and the "real deal".

The underlying assumption of legal drafters seems to be that meaning and control are in the words; if the content and wording is right, the appropriate behaviors will follow (Sless 2015, 195). However, it is not realistic to assume that once something is in a contract (or in legislation), compliance will automatically follow. Indeed experience and research suggest otherwise: controlling content does not necessarily control people's behavior, nor guarantee the desired outcome. People may choose not to read what they are supposed to. Or they may try to read it, but not understand it. If we want to make our contracts work, we need to make it easier for people to read, understand, and comply with them. This is where PPL and information design come in.

If we are to break the vicious circle, we need to make the current paradigm explicit and challenge it. We can begin with the basic truth that a judge is not a frequent contract user: the people in charge of negotiation and implementation are. Seen through the lens of PPL, contracts are business tools: shared, visible scripts (Haapio \& Haavisto, 2005) that support communication and collaboration (IACCM, 2015b) and empower the parties to understand their commitments; 
what they can expect from each other; and how to work together to create, share, and protect value. To fulfill this role appropriately, contracts need to be designed, not just drafted.

Figure 2.1 below, The Emerging View of the Purpose and Functions of Contracts, shows how the lens of PPL can provide a framework to facilitate a paradigm shift from current contract drafting practices to contract design. This has implications for both the process and the outcome, for contract development and implementation, as well as for the contract as a document. More attention needs to be paid to the presentation of contract content: first impressions, tone of voice, look and feel, structure, layout, and text navigation tools - all of these matter. By paying attention to these things, contracts can become more engaging, useful, and usable. They can then become useful and usable business tools or, as we will argue later, interfaces. ${ }^{7}$

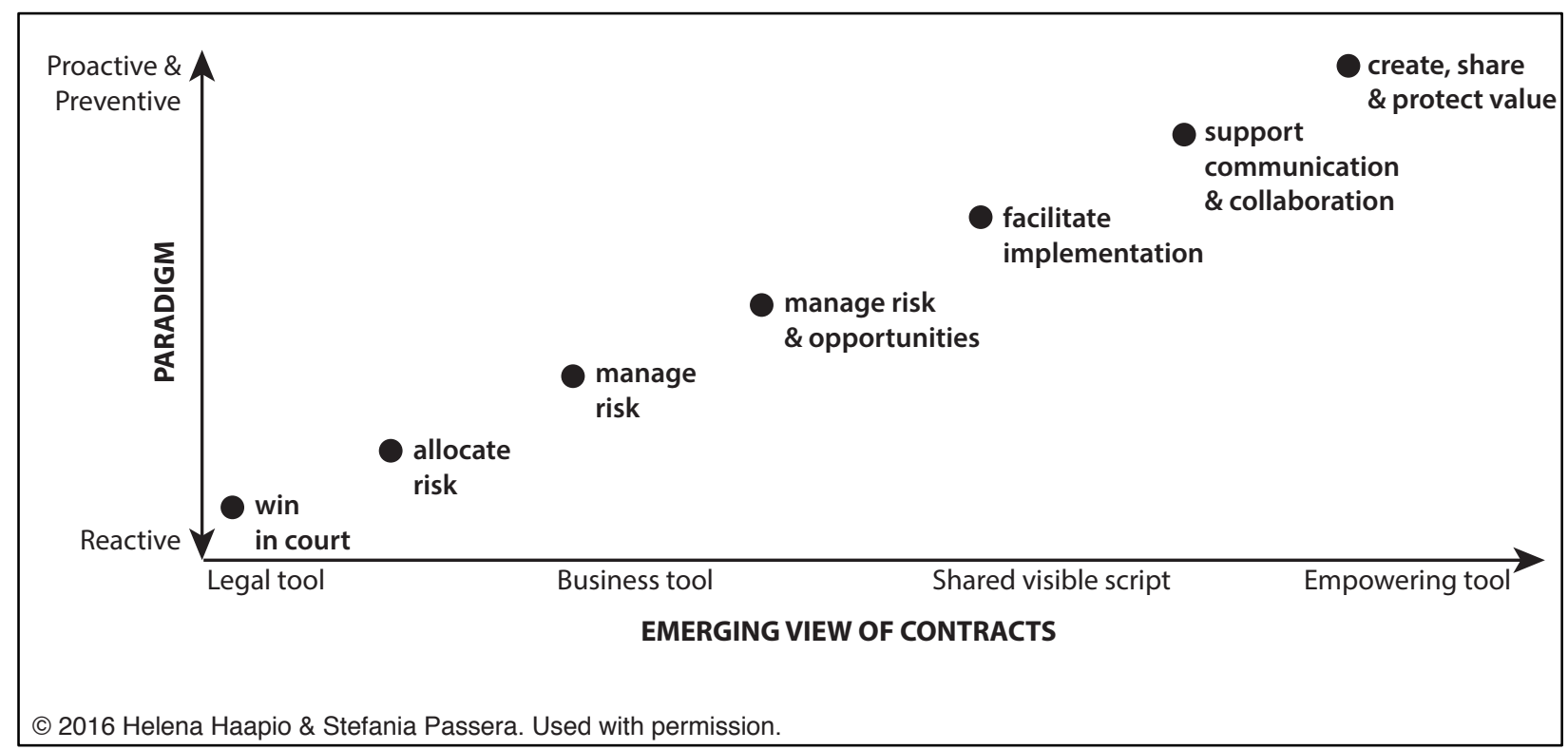

Figure 2.1: The emerging view of the purpose and functions of contracts (Haapio, 2016)

We are not alone in calling for a paradigm shift to remedy the current challenges facing contracts. Earlier research has explored, for example, the simplification of contract language and design (Kimble, 2002), visualization (Jones \& Oswald, 2001), and collaborative contracting (Barton, 2012). Taken together, these form an important part of the move towards PPL and next

\footnotetext{
${ }^{7}$ For our chosen metaphor of contracts as interfaces that facilitate interaction between organizations as well as between users and the information they need to do their jobs, see Section 3.
} 
generation contracts (Haapio, 2013a; 2013b; Haapio \& Barton, forthcoming). However, research on these possibilities is still in its infancy.

\section{Responding to the challenge: contract design}

In order to create contracts that work as useful and usable business tools, we need to bring business-specific knowledge, along with effective communication strategies, into contracts. For us, contract design is like a jigsaw puzzle that brings together technical, operational, financial, legal, and communication expertise (Haapio, 2013b, 37). From this perspective, legal expertise is just one piece of the puzzle.

Argyres and Mayer (2007) demonstrated that contract design is a potential source of competitive advantage. To develop this capability, it needs to become multidisciplinary. For example, managers and engineers are key repositories of deal-specific knowledge about roles, responsibilities, operations, and collaboration practices, and should be in charge of designing the relevant contract clauses. Lawyers, in turn, are likely to be best equipped to take care of contingency planning, dispute resolution, indemnities, and similar legal protections.

In order to orchestrate cross-professional contributions to a contract, we first need an information architecture to bring a consistent logic to the whole (Haapio \& Hagan, 2016). We then need to ensure that the content is presented in a logical, understandable, and functional way. For example it might be best to structure a contract thematically so that different interest groups (e.g., HR, finance, or production) can easily find the parts that are relevant for them. Then there are questions about how to make the content clear within each section: what is the best way to communicate, say, shipping quantities and schedules to production? Or the best way to communicate agreed KPIs and service levels to an implementation team and its manager?

In contrast to the idea of contracts as legal tools, we prefer the metaphor of contracts as interfaces. One set of interfaces is between organizations, allowing coordinated action and exchange (Koskinen \& Mäkinen, 2009; Schepker et al., 2014) and influencing the nature of the ongoing relationship (Weber \& Mayer, 2011). At the same time, there are also interfaces between users and the information they need to do their jobs. This is where we have focused our research, on what we call human-contract interaction (Passera \& Haapio, 2013). Our guiding 
question has been: what methods can we use to facilitate the interaction between people and contracts? How can we express the affordances ${ }^{8}$ of contracts through contract design?

Pursuing the idea of contracts as interfaces, we look next at how designers, engineers and others have learned to identify, collect, and share best practice to produce effective, usable, and intuitive information.

\section{A design patterns approach for contracts}

Experienced professionals can draw upon a number of solutions to problems they meet in their work, yet do not necessarily have names for them. Without names, the solutions can be hard to discuss or teach (Waller \& Delin, 2011, 1). This chapter proposes adopting from designers the use of design patterns: reusable models of solutions to commonly occurring problems.

Design theorist Christopher Alexander and his colleagues (1977) first used the concept of design patterns in architecture to create a common language for recurring sets of experiences and insights and codify them into a standardized collection of patterns. Each pattern first describes a problem which occurs repeatedly, and then gives the core of a solution which the designer can use over and over again, without repeating it precisely (Alexander et al., 1977, ix; Alexander, 1979). In fact, patterns offer model solutions without dictating exactly how they should be implemented. Pattern languages are designed for use by both experts and laypeople: a shared toolbox of robust, tested practices that improve communication between people working together on a project.

Inspired by Alexander's initial work, pattern libraries have become a way to share solutions, not only for architects, but also for interaction designers, software engineers, and information designers (e.g., Pan \& Stolterman, 2013; Tidwell, 2014; Waller \& Delin, 2011). Borrowing tools from these professions seems a natural continuation of the metaphor of contracts as interfaces. Contracts can be seen as information products (Haapio, 2013a; Kobayashi \& Ribstein, 2011, 1174; Orna, 2005), and so their crafter's work can be viewed as information design. In a number of contexts, the work of lawyers has been found to have similarities with the work of designers

\footnotetext{
${ }^{8}$ The concept of affordance - first introduced by Gibson (1977) in the field of ecological psychology, and then popularized by Norman (2002) in the field of design and human-computer interaction - indicates the possibilities of action and use that an object affords to its users. Norman in particular focused on perceived affordances, that is, how well an object intuitively communicates its functions.
} 
(e.g., Haapio, 2014a; Haapio \& Passera, 2013), architects (e.g., Fuller, 1981; Gerding, 2013), ${ }^{9}$ or engineers (e.g., Haapio, 2013b; Howarth, 2013), so much so that law has been viewed as engineering (Howarth, 2013; Mitchell, 2015) ${ }^{10}$ and lawyers as legal architects (Fuller, 1981; Haapio, 2013a; 2013b; Mitchell, 2015). A number of observers have also noted similarities between contract drafting and computer programming or coding (e.g., Gerding, 2013, 1323; Mahler, 2013).

We are not the first to explore the use of design patterns in this context. Gerding (2013) examined how Alexander's pattern language framework provides a unique lens to look at how transactional attorneys draft contracts. He explored the various functions contract patterns can perform, for example helping to deconstruct complex problems and bargains by breaking them into components, allowing teams of lawyers to work on different aspects of a contract or transaction simultaneously, or providing lawyers with devices they can use repeatedly to estimate quickly whether particular contract language solves certain bargaining problems, meets client objectives, and will be interpreted by courts in an anticipated manner (Gerding, 2013, $1328,1346)$.

In 2008, a Contracts Wiki approach was proposed by Triantis and Barnard ${ }^{11}$. The online platform provided modular contract terms through an online community creating new contract modules to solve problems arising from changes in regulation or the business environment. While its creators did not use the term pattern language, the idea was similar: to provide a resource to bring together good practice solutions to particular contracting problems, and to promote efficiency and standardization by disseminating these solutions. ${ }^{12}$

More recently, similar ideas have been implemented by a number of web-based resources which provide reusable contract forms, samples, and clause libraries, for both lawyers and non-lawyers. For example, Docracy (www.docracy.com) hosts a crowdsourced library of contracts that allows people to upload and share contracts on the platform. Legal Robot (legalrobot.com) and

\footnotetext{
${ }^{9}$ The metaphor of the lawyer as architect has been used in many contexts, varying from lawyers as architects of social structures to lawyers designing new ADR mechanisms.

${ }^{10}$ Howarth (2013) sees the work of lawyers as designing useful devices for clients; according to Howarth, lawyers can become more innovative and effective as designers of new devices by using the methods of engineers. Mitchell (2015) explores how lawyers can make their work-product a better product.

${ }^{11}$ See About the Contracts Wiki (n.d.); System Shocks and Collaborative Contract Innovation (n.d.). The Wiki was established with the sponsorship of Harvard Law School and the Berkman Center for Internet and Society.

${ }^{12}$ The Contracts Wiki did not succeed as a platform. Its webpage is still online, but it is not being actively maintained. (Haapio \& Hagan 2016).
} 
ContractStandards (www.contractstandards.com) aim to improve the contracting process by comparing current documents to standards and metrics.

Haapio and Hagan (2016) explored the value design patterns can offer in the contracting process, not just in terms of contracts as documents. Their approach widens the scope of the early proposals beyond patterns related to content, clauses, and language. They stress the need for patterns to present and communicate contracts and make them function properly. Their Contract Design Pattern Library website (www.contractpatterns.design) ${ }^{13}$ suggests four main categories of patterns: (1) Composition, (2) Visualization, (3) Process, and (4) Text. The "Composition Patterns" category highlights the importance of functional document elements that help navigate contracts, such as a table of contents, checklists, and summary pages. The "Visualization Patterns" category uses visual elements to help users find, understand, and experience the content in easier and more congenial ways. The "Process Patterns" category offers patterns of "actions that people involved in crafting, finalizing, and implementing a contract take in order to make it more useful and to accomplish the ends that it intends to" 14 such as creating a contract briefing document and holding a meeting to discuss it.

Waller et al. (forthcoming) use a pattern approach to describe their interventions in a contract simplification project for a global energy company wishing to engage local small contractors from First Nations communities in Canada. These patterns, too, go beyond language, offering solutions in terms of layered layout, compositional and functional elements (e.g., checklists), and explanatory visualizations (e.g., timelines and icons). The patterns were categorized according to their functions: supporting strategic reading, supporting explanations, supporting user response, supporting readers' engagement.

The approaches of Waller et al. (forthcoming) as well as Haapio and Hagan (2016) are the first in the contracting field to explicitly organize and structure design patterns around a combination of problem, solution, and rationale. A coherent and expandable organization is necessary to create pattern libraries, even though the way the patterns are structured usually depends on the field of application. For instance, Table 1 below (adapted from Waller \& Delin, 2011), shows five different structuring approaches, from three different fields:

\footnotetext{
${ }^{13}$ The Contract Design Pattern Library is an early stage prototype of what such a library may look like. It currently has a limited number of patterns, but welcomes suggestions and entries.

${ }^{14}$ See www.contractpatterns.design/patterns. For the difference between contract design patterns and contract templates, models, and standards, see Haapio \& Hagan 2016.
} 


\begin{tabular}{|l|l|l|l|l|}
\hline Alexander & Tidwell $^{\mathbf{1 5}}$ & Yahoo & Waller et al. & Haapio \& Hagan \\
\hline Architecture & Interface design & Interface design & Contract design & Contract design \\
\hline Number \& name & Name & Name & Name & Name \\
Photograph & Illustration & Illustration & Challenge & Illustration \\
Upward links & What & What problem & Typical solution & What \\
Problem & Use when & does this solve? & Typical issues & When \\
statement & Why & When to use this & Example & Why \\
Explanation & How & pattern? & & How \\
Sketch/diagram & Examples & What's the & & Examples \\
Solution & In other libraries & solution? & & \\
summary & & Why use this & & \\
Downward links & & pattern? & & \\
& & Accessibility & & \\
\hline
\end{tabular}

Table 1: Examples of pattern structures ${ }^{16}$

In the remainder of this chapter, we will focus on one of the pattern categories proposed by Haapio and Hagan (2016): visualization patterns.

\section{Contract visualization patterns: proposing a categorization}

The idea of using visual communication in the world of contracts has been previously explored both in our own research and in that of other scholars. Despite a common interest, the approaches described in the literature have been quite varied in terms of style, basic assumptions, and goals. The various labels used to describe these approaches include diagramming transactions (Conboy, 2014), graphical user-interfaces for legal texts (Mahler, 2013), visual interfaces for deal making (Plewe, 2013), and contract visualization (Passera \& Haapio, 2011). This variety can be reconciled by tidying up the library shelf of visualization patterns in Haapio and Hagan's (2016) pattern library. To do so, we offer a categorization of these approaches (Table 2) and a common language to describe them as solutions.

\footnotetext{
${ }^{15}$ Selected patterns from the book (Tidwell, 2014) are featured at designinginterfaces.com/patterns.

${ }^{16}$ Alexander, 1979; Alexander et al., 1977; Haapio \& Hagan, 2016; Tidwell, 2014; Waller et al., forthcoming; Yahoo, n.d.
} 


\begin{tabular}{|l|l|}
\hline \multicolumn{2}{|l|}{ Visualization Patterns } \\
\hline Categories & Examples \\
\hline $\begin{array}{l}\text { Visual organization } \\
\text { and structuring } \\
\text { patterns }\end{array}$ & $\begin{array}{l}\text { Searchable headings } \\
\text { Layered layouts } \\
\text { Typographic highlighting } \\
\text { Bulleted and numbered lists }\end{array}$ \\
\hline $\begin{array}{l}\text { Multimodal } \\
\text { document patterns }\end{array}$ & Comic-based contracts \\
\hline $\begin{array}{l}\text { Visual representation contract guides } \\
\text { patterns }\end{array}$ & $\begin{array}{l}\text { Timelines } \\
\text { Tables }\end{array}$ \\
& $\begin{array}{l}\text { Flowcharts } \\
\text { Swimlanes }\end{array}$ \\
& Companion icons \\
& Delivery diagrams \\
\hline
\end{tabular}

Table 2: Categorization of contract visualization patterns

Our first category of contract visualization patterns, Visual organization and structuring patterns, is the least obviously visual. Their function is to organize and structure texts visually by means of layout, page design, and typography in order to increase readability and legibility and support strategic reading activities such as searching, skimming, and selecting relevant content. Waller (2012) sees page layout as the infrastructure for effective reading and writing because it provides a hierarchy and the visual cues necessary to navigate information on the page.

Customarily, contracts are highly textual documents: organizing and structuring the text is the first step towards making the content accessible and usable to readers. A key reference for this approach is Butterick's “Typography for Lawyers" (2015), a concise compendium on why typography, fonts, and page design matter, and how they contribute to polished, legible, and clear legal documents. Waller has written extensively on typography and page design, ${ }^{17}$ and with his co-authors (Waller et al., forthcoming) provides examples of several effective layout patterns for contracts, such as left-handed headings to facilitate skimming, thematic color-coding to signal different parts of the document, or multi-column layered layouts to accommodate explanations, examples, and definitions. Tsygankova (2016) suggests highlighting key parts of the text with italics, boldface, or color to capture attention. For instance, bulleted and numbered lists can be used to clearly communicate hierarchies, steps, or a family of items; in general, the aim is to avoid a cluttered and dense first impression, which scares potential readers away (Plain Language Action and Information Network, 2011).

\footnotetext{
${ }^{17}$ See www.robwaller.org/writing.html
} 
Typographic and layout patterns are important but relatively conservative solutions. It suggests that contract designers do not have the will, time, tools, or skills to explore more visual solutions, or feel that the time taken to produce them is unreasonable. If the status quo of contract-as-text is not challenged, however, other communication possibilities will be missed that could ensure substantially better understanding and engagement.

To this end, the category Multimodal document patterns challenges the idea of contracts as something purely textual. These solutions are about transforming contracts into more visual documents where text and images are fully integrated. In fact the first impression of the document is something visual, rather than textual: not a typical contract. This opens up the possibility of visualizations not only in contracts but also beyond: as contracts and about contracts (Haapio et al., 2016). Take, for example, comic-based contracts (Haapio et al., 2016; Keating \& Andersen, forthcoming; Plewe \& de Rooy, forthcoming). Here meaning arises by text and visuals coming together to create a narrative. They cannot be separated: the comic $i s$ the contract. This approach has been successfully applied to employment contracts for low-literacy audiences in South Africa by Robert de Rooy (Haapio et al., 2016; Plewe \& de Rooy, forthcoming), and used for experimenting with non-disclosure agreements for researchers at a University Engineering School in Australia (Keating \& Andersen, forthcoming). Visualizations about contracts are exemplified by the visual contract guide, an explanatory document which consists of a full collection of visual/multimodal explanations of a (textual) contract. This pattern first appeared in the guidance notes and flowcharts for the New Engineering Contract (NEC) family of contracts, which are used, for instance, in the construction industry and for large projects (e.g., NEC 2013a; 2013b): each page features one flowchart about a specific contract topic, with cross-references to the relevant contract clauses. Passera, Pohjonen, Koskelainen and Anttila (2013) created and tested such a visual guide for the terms of public procurement of services in Finland (JYSEn käyttämisopas 2013), demonstrating how the meaning of the terms was more accurately and quickly understood in this format. ${ }^{18}$

Lastly, we identify the category of Visual representation patterns. Here the focus is on representing the logic, content, or prerequisites of contracts through a diagrammatic or pictorial

\footnotetext{
${ }^{18}$ The approach works for conventions also, see, e.g., Visual CISG (Passera, Haapio et al., 2013; Haapio 2014b, 722). A prototype booklet was created by information designers and lawyers, as the result of their collaboration during the Information Design Summer School 2013 in Syros, Greece. The CISG is the uniform international sales law of countries that account for the most part of all world trade.
} 
representation. The goal is to explain the text, with visual communication used to make visible the abstract relationships within information, e.g., sequences, transitions, interactions, or hierarchies. Visual representations do not usually substitute for text, but complement and disambiguate it. In fact, textual elements are a key element within diagrams: they provide conceptual labels and meaning to its components. Making relationships between concepts visible constrains possible interpretations and guides inferences (Stenning \& Oberlander, 1995), helping comprehension. The cognitive cost of comprehension is also reduced, since the external representation pre-processes and integrates the information in a meaningful model, which can be simply be "read off" instead of having to be created in the reader's mind (Scaife \& Rogers, 1996). These effects have also been observed in experimental studies specifically on contracts: in comparison to pure text, the presence of visual representations significantly improves comprehension accuracy and speed (e.g., Mamula \& Hagel, 2015; Passera, 2015; Passera, Kankaanranta \& Louhiala-Salminen, forthcoming; Passera, Pohjonen et al., 2013;).

While there are many different representation techniques, ${ }^{19}$ some seem to recur in contract research and practice, signaling their pattern-like nature. We have identified the following six as key visual representation patterns:

- Timelines

(Mamula \& Hagel, 2015; Passera \& Haapio, 2011; Passera, Pohjonen et al., 2013; Waller et al., forthcoming)

- Flowcharts

(Conboy, 2014; Jones \& Oswald, 2001; NEC, 2013a; 2013b; Passera, Pohjonen et al., 2013)

- Tables $^{20}$

(Australian Office of Parliamentary Counsel, 2013; Kimble, 2002; Plain Language

Action and Information Network, 2011; Strylowski, 2013)

- Swimlanes

(Passera, Pohjonen et al., 2013; Passera, Smedlund \& Liinasuo, forthcoming)

- Companion icons

(Haapio \& Hagan, 2016; Passera, 2015; Waller et al., forthcoming)

\footnotetext{
${ }^{19}$ See Lengler \& Eppler, 2007; Meirelles, 2013.

${ }^{20}$ Our references suggest the use of tables in legal documents generally. The examples in this paper show their application to contracts.
} 
- Delivery diagrams

(Passera, Haapio et al., 2013; International Chamber of Commerce, 2010)

These visual representation patterns can be used flexibly for different purposes: in contracts, as explanatory complements (Mamula \& Hagel, 2015; Passera, Kankaanranta \& LouhialaSalminen, forthcoming; Haapio et al., 2016); about contracts, as the building blocks of visual contract guides (Passera, Pohjonen et al., 2013); and for contracts, as templates and tools to be used in negotiations to support thinking, promote understanding, and generate content for the agreement (Passera, Smedlund \& Liinasuo, forthcoming; Plewe \& de Rooy, forthcoming; Plewe, 2013; Haapio et al., 2016; Siedel, 2016).

\section{Visual representation patterns}

Given the limited scope of this chapter, we can only present a handful of patterns in detail. Since visual representation patterns have been at the core of our research and professional experience, they are a natural choice.

The metaphor of contracts as interfaces has guided us to develop our pattern structure, adapting the work of Tidwell (2014), Waller and colleagues (forthcoming) and Haapio and Hagan (2016). Our pattern structure includes a name to identify the pattern, and a short description of its essence. We continue by providing examples of communication problems in contracts, and how the pattern offers a solution. We then provide examples of the pattern in the context of contracts. In essence, after identifying a useful, repeatable solution to a common contract-related problem, we have given it a name and a description so that it can join a future contract designers' repertoire of potential solutions to similar problems. ${ }^{21}$

\footnotetext{
${ }^{21}$ While a number of design tools and software are available to create visual representations, we have chosen not to mention them here. The essence of design patterns is technology-independent, and specific tools or software may become obsolete.
} 


\subsection{Timeline pattern}

What is it - Timelines represent time or duration, a series of steps or processes taking place within a given timeframe, or a sequence of events.

When to use the pattern - Timelines are useful for clauses that specify duration (e.g., contract term, or notice or warranty period), list milestones, to-do's and deadlines (e.g., payment or reporting schedules), or describe steps or processes (e.g., to terminate the agreement, give notice, perform an audit).

Rationale for using the pattern - Timelines provide an explicit and concrete representation of time and the order of steps to be taken, which are often abstract and hidden in the text or appendices. Timelines help to explain complex processes by illustrating the steps that need to be taken, when, and in what order. Presenting actions, requirements, or deadlines in chronological order makes sense to readers, as it mirrors their lived experience: they can see at a glance what will happen in the future, and what course of action to take.

How to apply the pattern - Time can be represented as a straight or circular line (Meirelles, 2013). Straight lines are suitable for representing progress, sequences, and procedures (Figure 6.1). Circular lines are suitable for representing recurring events or deadlines on a weekly, monthly, quarterly, or yearly basis (Figure 6.2). Milestones, deadlines, and actions are marked on the timeline as, for instance, dots, tacks, shapes, or call-out boxes. Textual elements can be used to clarify and label the key parts of the timeline.

The basic pattern can be applied to create more complex time-related representations, e.g., processes that take different paths (Figure 6.3), variables changing over time (Figure 6.4), and the synchronous progress of multiple processes or events (Figure 6.5). 


\section{Examples}

This Agreement shall be valid for three (3) years from the date of signing.

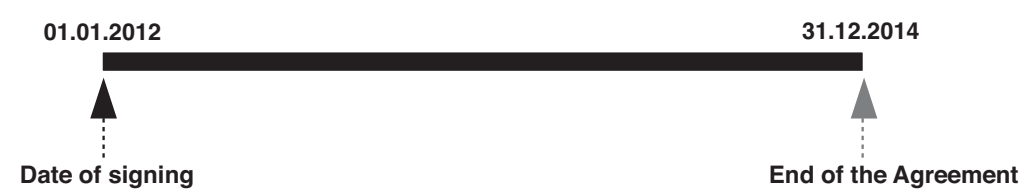

This Agreement shall be valid for an initial period of three (3) years from the date of signing. Unless either Party gives notice of termination at least six (6) months before the expiry of the three-year period, it shall remain in force until further notice, with a notice period of at least three (3) months. Notice shall be given in writing.

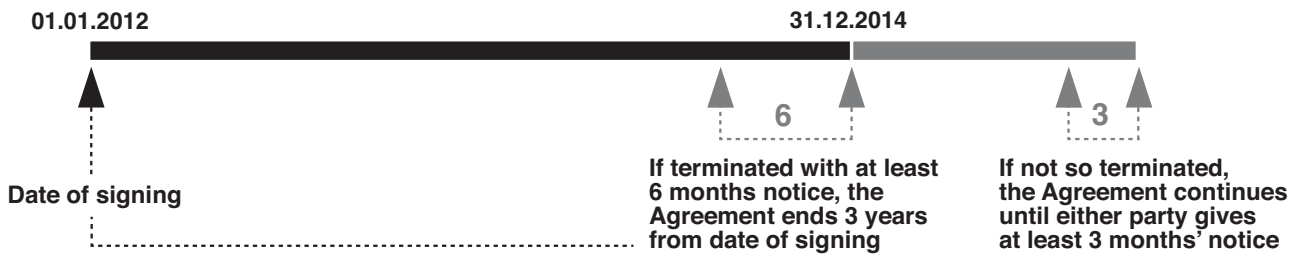

This Agreement shall be valid for an initial period of three (3) years from the date of signing. Unless either Party gives notice of termination at least six (6) months before the expiry of the three-year period, it shall remain in force for additional periods of one year at a time, provided it has not been terminated at least three (3) months before the expiry of such one-year period. Notice shall be given in writing.

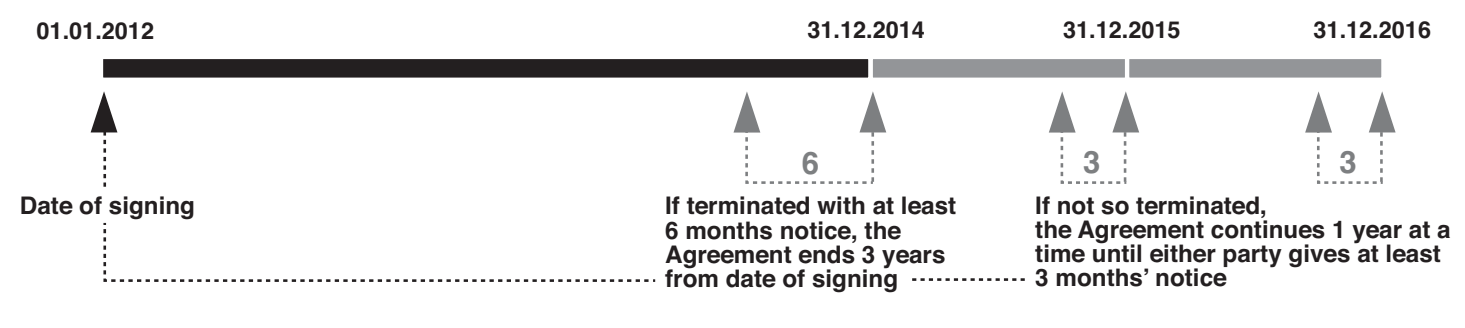

2012 Stefania Passera \& Helena Haapio. Used with permission.

Figure 6.1: Examples of "linear" timelines, representing different types of term and termination provisions. Time is represented as a straight line, with key events (e.g. contract commencement and end, contract years, when to give notice) marked on it. Color can be used to distinguish, for instance, between fixed and optional contract periods. 
The Supplier shall send to the Customer regular reports, as follows:

a) A report on service performance, assessed against Key Performance Indicators (KPI), every two months, the first report to be submitted in February

b) A report detailing the results of the service quality audit, yearly, each November

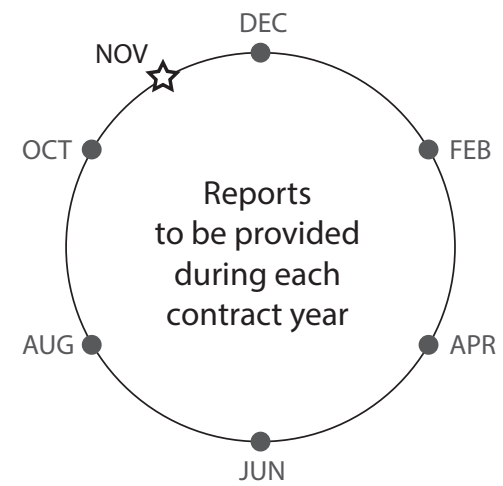

- Service performance against KP

$\hat{\sim}=$ Service quality audit results

C 2016 Stefania Passera \& Helena Haapio. Used with permission.

Figure 6.2: Example of a "cyclical" timeline which illustrates when the supplier needs to submit periodic reports to the customer. Time is represented as a circle, to indicate that the same events repeat each year. Different colors and shapes can help distinguish between different types of reports to be submitted.

In the event that the Equipment does not fulfill some of the guarantee values specified in Appendix 1 during the Test Run(s), the Supplier shall as soon as possible and not later than within one (1) month, at its own expense and at a time convenient to the Purchaser, remedy the deficiencies noted, after which a new Test Run shall be carried out. If the guarantee values are still not attained in this renewed Test Run, the Supplier shall, at its own expense, without delay and within a maximum period of two (2) months, effect the necessary improvements and modifications to the Equipment. If the guarantee values are not attained in the subsequent Test Run, the Purchaser is entitled to liquidated damages in accordance with Appendix 8.

\section{Test runs process}

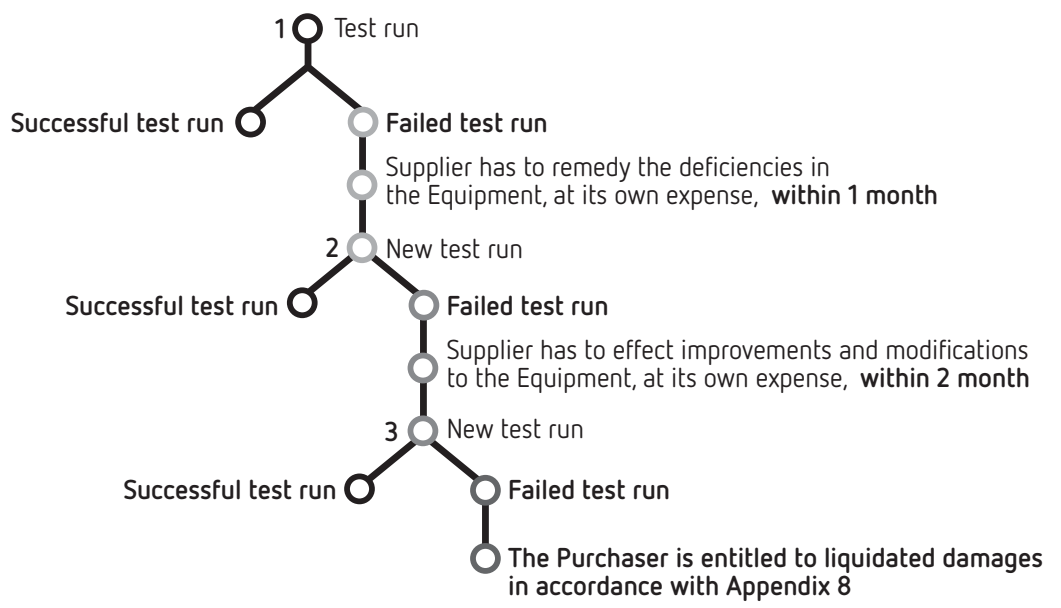

2012 Stefania Passera. Used with permission.

Figure 6.3: Timeline representing the test run process in an Equipment Sale and Purchase Agreement. Test runs are usually part of the acceptance process: simply put, the equipment needs to perform to performance specifications in a series of tests before the purchaser will accept it. If the equipment does not perform as promised, in this case, the supplier needs to remedy the deficiencies and try to pass the test again. Since the test can be passed or failed, the timeline bifurcates, showing both scenarios. 


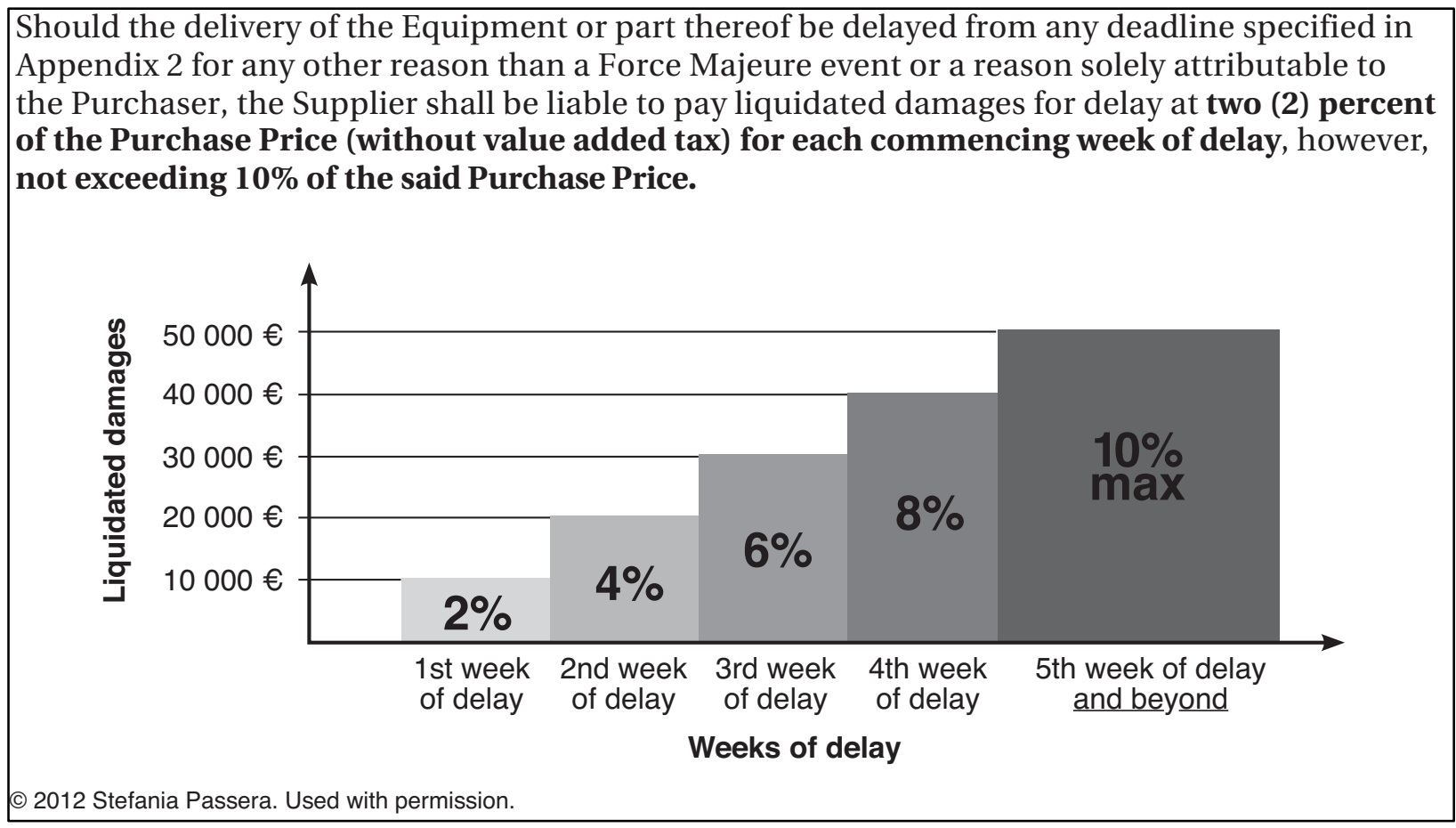

Figure 6.4: This is a hybrid between a timeline and a bar chart, and represents liquidated damages for delayed delivery in an Equipment Sale and Purchase Agreement. The horizontal axis represents weeks, the vertical axis the liquidated damages to be paid by the supplier. The bar chart is positioned within the axes and shows the liquidated damages rate for each commencing week of delay, capped at 10 percent of the purchase price.

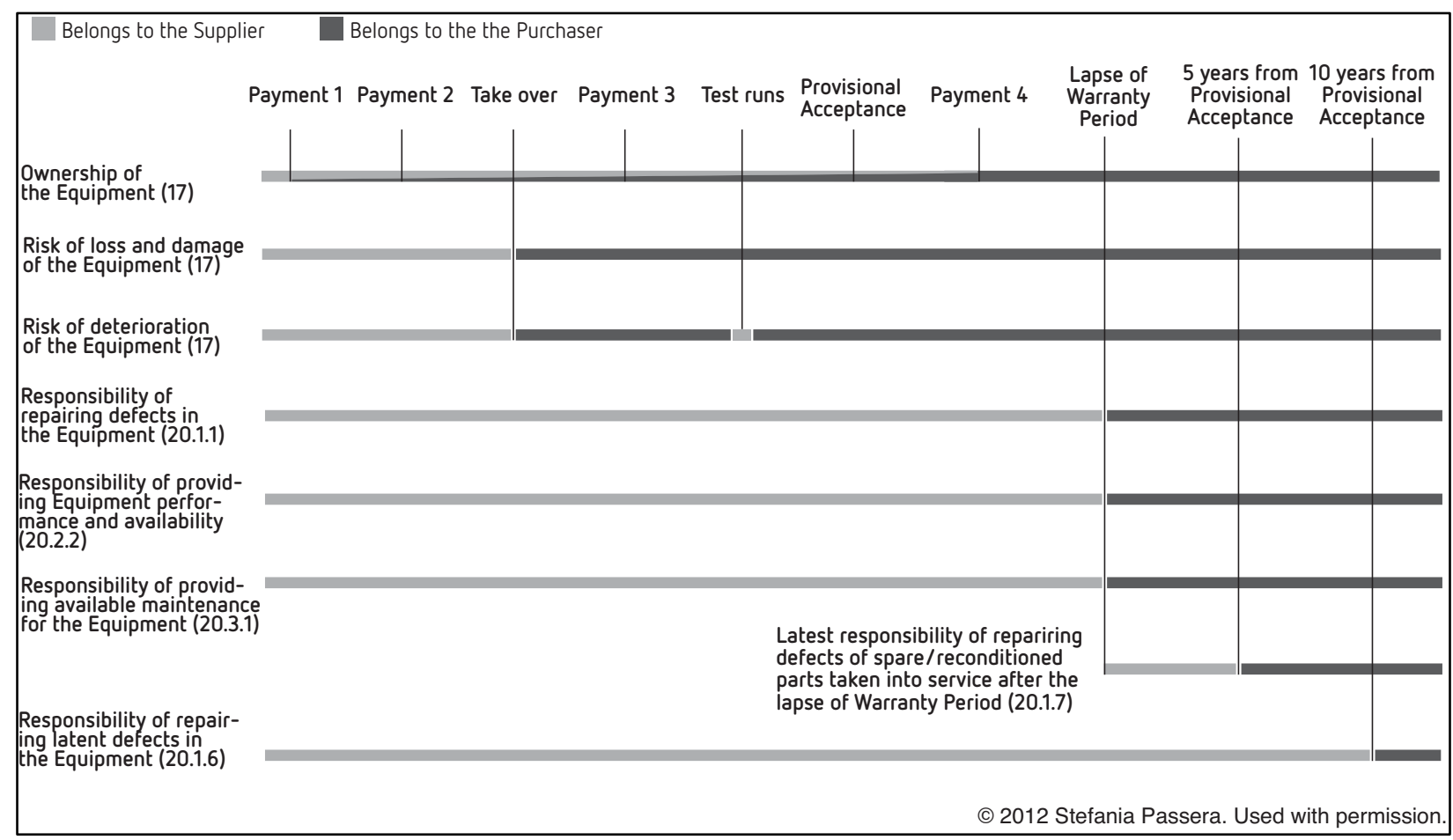

Figure 6.5: Multiple timelines can be stacked and presented together to show how important events take place in time. This example illustrates how title, risk and responsibility for a piece of equipment pass from the supplier to the purchaser, showing how the "moment of passage" is different for different types of risks and responsibilities. (For reasons of space, the multiple timelines are presented here without the accompanying 6 clauses of the Equipment Purchase and Sale Agreement). 


\subsection{Flowchart pattern}

What is it - Flowcharts represent, in a step-by-step fashion, a workflow or a process. They are tools to support decision-making and problem-solving. They also allow us to identify the actual flow or sequence of events in a process.

When to use the pattern - Most contract readers are busy people and need quick, clear answers from the contract to inform their actions. However, two typical features in contracts hinder straightforward answers. Firstly, since they usually describe many contingencies, contracts are full of conjunctions that indicate "conditional information" (e.g., if.../then ...; in case of.../NN shall...), exceptions (e.g., notwithstanding; unless), and alternatives (e.g., either.../or ...; whichever the earliest or highest). Secondly, cross-references are another typical feature of contracts that force readers to divert their attention to other clauses, appendices, or defined terms. These features make contracts hard to understand because they require readers to perform cognitively demanding operations: split their attention, keep in mind several chunks of information, and integrate them into something meaningful.

Rationale for using the pattern - Flowcharts offer a step-by-step approach to solving complex problems or taking decisions, by presenting simple, straightforward actions. Users do not need to keep in mind all the information they will need at once, but can consider one step at a time. Moreover, flowcharts present all the relevant information on one page in an integrated way so that it is easily accessible. Decision points, alternative paths, and possible outcomes are visible at a glance.

How to apply the pattern ${ }^{22}$ - Flowcharts consist of a series of blocks of text connected by arrows. The text in the blocks is often formulated as a simple question that can be answered with a yes or a no. Two arrows, one marked "yes" and the other marked "no", lead from each block. Depending on their response, users follow the appropriate arrow to the next question and so on until they have an answer to their question. In general, flowcharts are more understandable when they run left-to-right or from top-to-bottom (Michael \& Hartley, 1991).

\footnotetext{
${ }^{22}$ Since our interest is on design patterns as model solutions to problems, we do not introduce formal representation methods for flowcharts. Such techniques have been standardized, for example, in the field of information technology, where there are precise representation rules - e.g., a diamond shape indicates a decision point, a rectangle indicates a process, and so on (ISO 5807:1985).
} 


\section{Examples}

$\mathbf{1 0 . 8}$ - If the price is not fixed, the customer shall have the right during the contract period to propose a price adjustment corresponding to the general cost trend of the supplies. If no unanimity is reached on the price adjustment and the customer considers that it cannot continue the contract under the prevailing prices, the customer shall have the right to terminate the contract with a notice period of two (2) months.

Notice of termination must be made in writing. If the customer does not give notice of terminating the contract, the contract shall continue using the prices prevailing before the price adjustment proposal or using other prices agreed together by the contracting partners in price adjustment

negotiations after the price adjustment proposal.

$\mathbf{1 0 . 9}$ - If not otherwise agreed, the contracting parties may propose price adjustments in the ways described above at the earliest twelve (12) months after the contract came into force and at intervals of not less than twelve (12) months.

10.10 - In the event of the customer giving notice of terminating the contract on the grounds presented in this section, the supplier shall be obliged if the customer so wishes to deliver the supplies at the prevailing prices, however at most six (6) months from the ending of the

contract.

Text source: The Ministry of Finance, Finland.

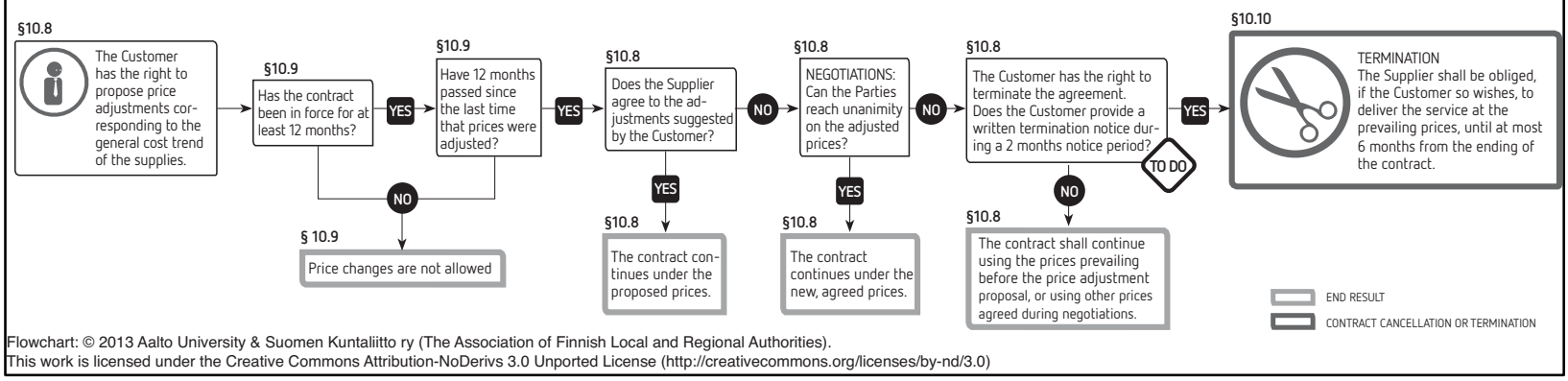

Figure 6.6 This flowchart, used in a visual guide for public procurement terms (JYSEn käyttämisopas, 2013), illustrates a price change procedure and the preconditions for requesting a price change. Different outcomes are set out, and color-coding indicates whether disagreements may escalate into contract termination. Each block of text in the flowchart cross-references the contract clauses, so that the diagram and text can be used together to further understanding.

\subsection{Table pattern}

What is it - A table is a systematic way to arrange facts and figures in rows and columns, so that information can be searched and skimmed more easily.

When to use the pattern - Dense, long texts make it difficult for the readers to discern key points of the content. Readers may want to compare information and make correct choices based on these comparisons: for instance, they may need to understand how a provision applies to different actors or in different circumstances, or what the rights and obligations of different parties are in relation to an issue, for example intellectual property rights.

Rationale for using the pattern - Tables provide a way of structuring information that helps readers to skim and process a lot of information at a glance: tables can be read very rapidly. They also facilitate comparison and choice between different elements. Like flowcharts, tables also bring together information that may be on different pages. Tables are not suitable for conveying complex processes or contingencies, but they are helpful in simpler tasks that can be performed 
quickly, such as finding relevant information from a long list, or comparing and choosing alternatives. Another advantage of tables is that people are generally familiar with their structure and should have no problems in understanding how they work. ${ }^{23}$

How to apply the pattern - All tables consist of rows and columns, with content placed in the resulting cells. Informative, clear headings are important to specify how the content is categorized in the columns and rows. The information hierarchy can be communicated by font size, use of boldface, color, and table lines of differing thickness (e.g., a thicker line between two rows can indicate a separation between different categories; thinner lines can indicate a separation between sub-categories within the same category). Bulleted lists can be used within cells to further chunk content (Figure 6.7). Color-coding and icons can also be included in tables to signal, at a glance, key differences among the cells (Figure 6.8).

\footnotetext{
${ }^{23}$ Tables are ubiquitous in organizational life. Some readers with a background in project or risk management may be familiar, for instance, with RACI charts, various types of matrices, and risk registers.
} 


\section{Examples}

\begin{tabular}{|c|c|c|c|c|c|}
\hline \multicolumn{6}{|c|}{$\begin{array}{l}10.2 \text { Inventing Party may transfer Ownership of Foreground Information to a third party. Prior to the transfer of } \\
\text { Ownership of Foreground Information to any third party during Programme and within twenty four months from the } \\
\text { end of Programme the other Parties shall be offered Ownership of Foreground Information on the same terms and con- } \\
\text { ditions as agreed with the third party. Party transferring its Ownership to Foreground Information is obliged to transfer } \\
\text { its rights and obligations arising from this Agreement. }\end{array}$} \\
\hline \multicolumn{6}{|c|}{$\begin{array}{l}\text { 10.3 Party having Ownership of Foreground Information has the right to grant third parties licences to Foreground } \\
\text { Information. However, Party having Ownership is obliged to inform during Programme the other Parties about such } \\
\text { grant of licence within } 30 \text { days from the execution of license. For the avoidance of doubt, such obligation to inform is } \\
\text { not applicable to licensing of a Party's product or services in the ordinary course of business. }\end{array}$} \\
\hline \multicolumn{6}{|c|}{ h Party shall be granted a royalty-free Access Right to Foreground Information. } \\
\hline \multicolumn{6}{|c|}{$\begin{array}{l}\text { 10.5 Notwithstanding anything to the contrary under this Agreement, Access Right includes a right to sublicense } \\
\text { Foreground Information solely to 1) a Party's subcontractors and even then, only for Party's own research or develop- } \\
\text { ment work or business operations, and 2) the users of a Party's end product or service, particularly in case of software, if } \\
\text { elements of Foreground Information are included in a Party's product or distributed appended to it. }\end{array}$} \\
\hline \multicolumn{6}{|c|}{$\begin{array}{l}\text { 10.6 Each Subcontractor shall be granted a royalty-free Limited Access Right to Foreground Information. Subcon- } \\
\text { tractors shall not have Ownership of Foreground Information they have invented, created or generated under Pro- } \\
\text { gramme. Ownership of such Foreground Information shall belong to Party/Parties that have engaged Subcontractor, } \\
\text { and such Party/Parties shall ensure the assignment of Ownership of Foreground Information from its Subcontractor to } \\
\text { Party/Parties concerned. }\end{array}$} \\
\hline WHO & $\begin{array}{l}\text { RIGHT TO FOREGROUND } \\
\text { INFORMATION (FI) }\end{array}$ & $\begin{array}{l}\text { RIGHT TO TRANSFER } \\
\text { OWNERSHIP }\end{array}$ & RIGHT TO LICENCE & RIGHT TO SUBLICENCE & $\begin{array}{l}\text { DURATION } \\
\text { OF THE RIGHTS }\end{array}$ \\
\hline $\begin{array}{l}\text { INVENTING PARTY \& } \\
\text { THEIR GROUP ENTITIES }\end{array}$ & Ownership (10.1) & $\begin{array}{l}\text { Yes, as long as (10.3): } \\
\text { - Rights and obligations arising } \\
\text { from this Agreement are transferred } \\
\text { as well; } \\
\text { - Other Parties have priority over } \\
\text { third parties: they have the right to } \\
\text { be offered Ownership on the same } \\
\text { terms agreed with third parties } \\
\text { until } 24 \text { months from the end of } \\
\text { Programme. }\end{array}$ & $\begin{array}{l}\text { Yes, but (10.4): } \\
\text { - Not exclusively; } \\
\text { - There is an obligation to } \\
\text { inform the other Parties } \\
\text { during the Programme } \\
\text { within } 30 \text { days from } \\
\text { the execution of license. }\end{array}$ & $\mathrm{N} / \mathrm{A}$ & $\begin{array}{l}\text { No time limit, } \\
\text { unless Ownership } \\
\text { is transferred }\end{array}$ \\
\hline $\begin{array}{c}\text { OTHER PARTIES \& } \\
\text { THEIR GROUP ENTITIES } \\
\text { TEI } \\
\end{array}$ & $\begin{array}{l}\text { Royalty-free Access Right } \\
\text { (non-exclusive, irrevocable } \\
\text { and perpetual licence and } \\
\text { right to use Fl in R\&D work } \\
\text { and business operations) } \\
\text { (10.4) }\end{array}$ & No & No & $\begin{array}{l}\text { Only in these cases (10.7): } \\
\text { - To subcontractors for Party's } \\
\text { own research or development } \\
\text { work or business operations } \\
\text { - To users of a Party's end } \\
\text { product or service, if elements } \\
\text { of fl are included in a } \\
\text { Party's product or distributed } \\
\text { appended to it }\end{array}$ & $\begin{array}{l}\text { No time limit. } \\
\text { Note however that a } \\
\text { license to Background } \\
\text { Information may be } \\
\text { needed. }\end{array}$ \\
\hline SUBCONTRACTORS & $\begin{array}{l}\text { Royalty-free Limited } \\
\text { Access Right } \\
\text { (non-exclusive right to use } \\
\text { Fl to the extent it is neces- } \\
\text { sary for carrying out work } \\
\text { within the Programme) } \\
\text { (10.6) }\end{array}$ & No & No & No & $\begin{array}{l}\text { For as long as Access } \\
\text { Right to Fl is neces- } \\
\text { sary for carrying out } \\
\text { work within } \\
\text { Programme. }\end{array}$ \\
\hline
\end{tabular}

Figure 6.7: This excerpt from the FIMECC (now DIMECC) Consortium Agreement helps compare and contrast the intellectual property rights that different parties have in relation to the IP created during the project (foreground information, FI). While this table could work with textual content only, icons are used to indicate the parties. These elements are functional, not decorative; they are used consistently throughout the Agreement. DIMECC (www.dimecc.com) is an open-innovation community facilitating joint R\&D between Finnish companies: access to IP is thus an important issue for its participating organizations. 


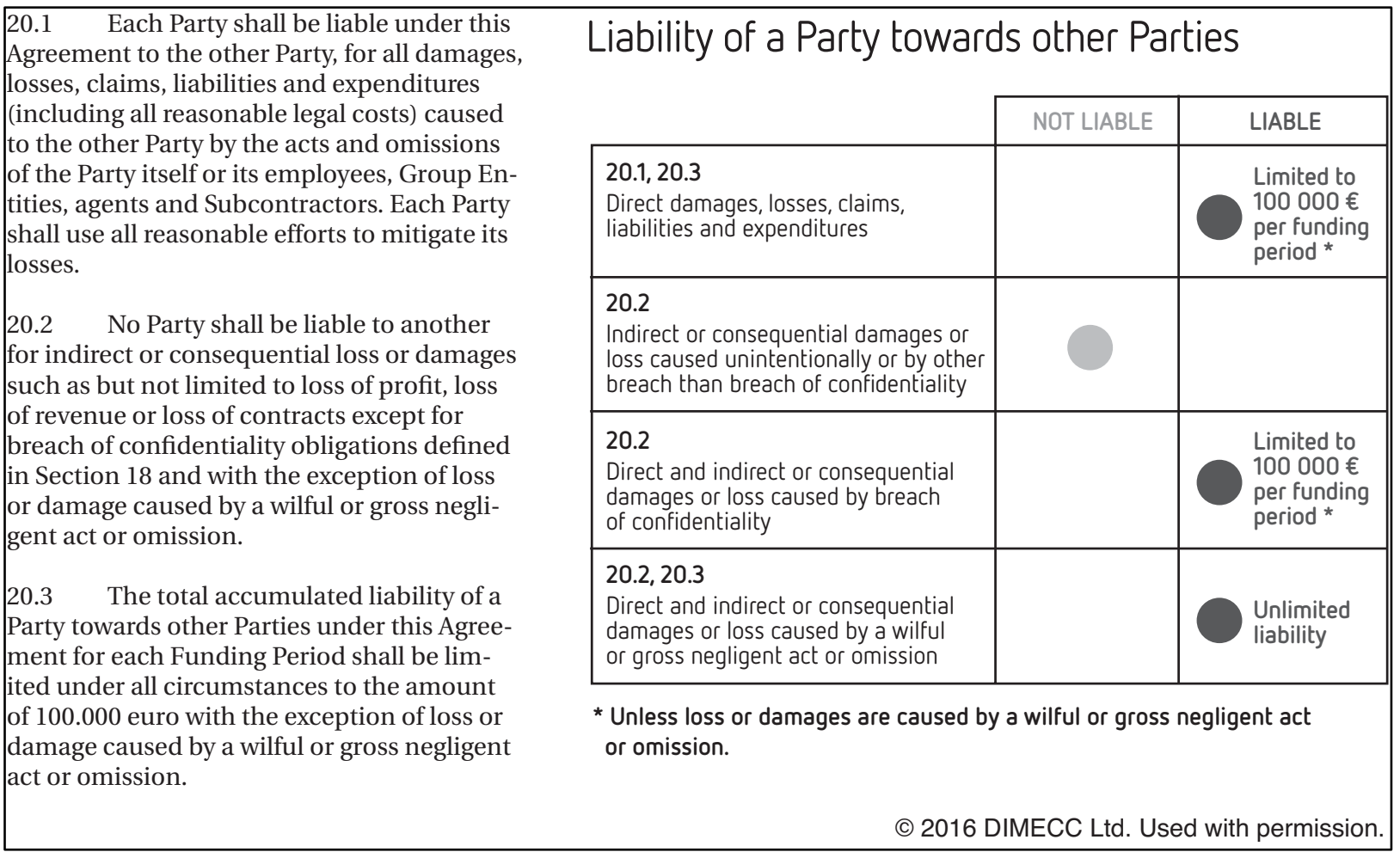

Figure 6.8: Excerpt from the FIMECC (now DIMECC) Consortium Agreement. This table uses structure and colorcoding (not visible in this greyscale reproduction) to communicate quickly the parties' liability, and whether there is a limit to it. The salient colored elements signal at a glance that there is a difference, even before reading the content of the cells. The table can be considered a decision chart, since the content is organized through a yes/no logic (liable/not liable).

\subsection{Swimlane pattern}

What is it - A swimlane is a diagram which shows how roles, rights, tasks, responsibilities, obligations, liabilities or remedies are distributed between different actors.

When to use the pattern - A major part of any contract is about assigning rights, obligations, and responsibilities to the parties. Especially with long, complex contracts, users may struggle to keep track of them all, especially since they need to be recovered from different clauses, often even different documents. During the contract creation stage, this may lead the parties to forget to agree on some of them, or believe that they have already assigned them, when in fact they have not. During the contract implementation stage, all parties need to have quick and easy access to their share of the promises if they are to deliver on them.

Rationale for using the pattern - Swimlanes can promote collaboration between the parties, because they clarify who needs to do what, and whether a responsibility is shared. They provide 
a concise summary to help people to understand their roles and responsibilities, align expectations, and to monitor the contract. They allow the parties to spot whether the contract is balanced and collaborative, or whether most of the responsibilities weigh on just one party. They can also be used to make the parties aware of areas where the contract remains silent.

How to apply the pattern - Each party is represented by a lane, drawn horizontally or vertically. Responsibilities, obligations, and rights are represented as blocks of text, and are "assigned" to a party by positioning them in the appropriate lane, while shared items are placed in-between lanes (Figure 6.9). If the tasks are part of a process, a flowchart can be superimposed over the swimlanes: in this way, the parties become more aware of any possible interdependencies between their actions, while knowing what is required from either or both of them, and when.

\section{Examples}

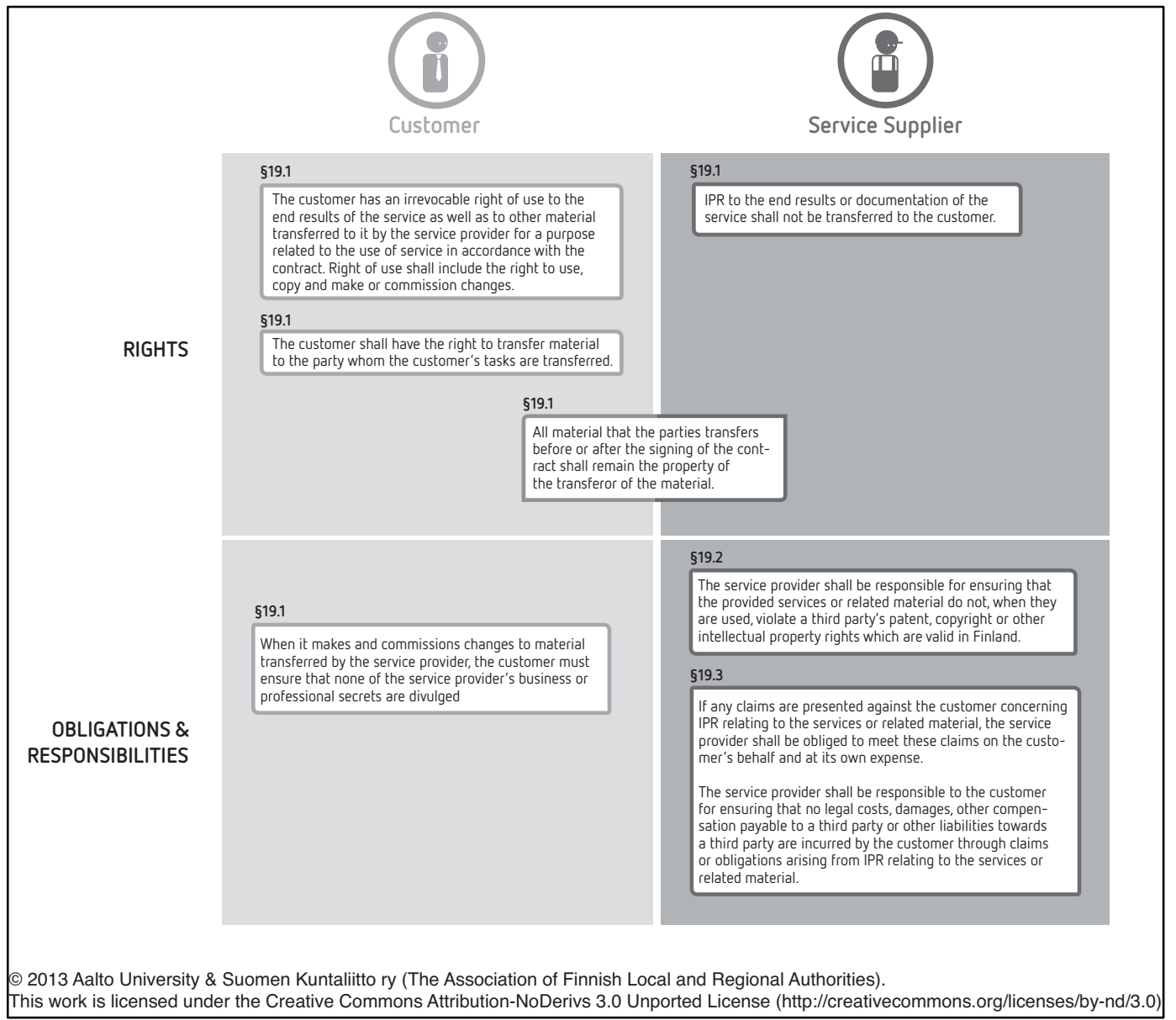

Figure 6.9: This swimlane, used in a visual guide for public procurement terms (JYSEn käyttämisopas, 2013), illustrates how intellectual property rights are allocated between the parties. Icons and color-coding (not visible in this greyscale reproduction) contribute to distinguish the two lanes, and extra textual labels on the left of the swimlanes help distinguish further between rights and responsibilities/obligations. Clauses and excerpts from clauses are placed verbatim in the swimlane, so as to avoid discrepancies between the original terms and the visual guide. 


\subsection{Companion icon pattern}

What is it - Companion icons are crisp, graphic symbols that represent the meaning or function of the textual element they accompany.

When to use the pattern - A typical contract is long and presented in an undifferentiated way. The visual cues to help skim and search the document are often limited to headings and clause numbers. These are often not very informative at a first glance: the meaning remains hidden in the text, not accessible to busy or distracted readers who are not reading the contract line by line.

Rationale for using the pattern - Icons act as visual cues, capturing readers' attention. In this way, salient content is also given a salient appearance. Thanks to icons, readers can search and identify relevant information quickly. While icons cannot provide sophisticated explanations of the terms, they bring their general meaning to the surface. When the same icons are used consistently throughout one or more documents, their meaning becomes more and more familiar to users, who can then identify at a glance recurrent topics and terms (e.g., "customer" and "service supplier" icons in Figure 6.9; "inventing party", "other parties" and "subcontractors" icons in Figure 6.7). As a general rule, icons in contracts should be used only as a complement to and not as a substitute for text, in order to avoid misunderstandings.

How to apply the pattern - Companion icons in contracts are often highly symbolic and metaphoric. They may refer to abstract concepts and terms. This is why we recommend using them with text or near to headings, since abstract concepts are not self-evident. Wherever possible we recommend using well-known icons that users are likely to interpret correctly (e.g., a shopping cart can indicate a purchase; a triangle sign with an exclamation mark can indicate a warning or something to pay attention to; currency symbols can indicate payments). They need to be chosen with the audience's previous knowledge and cultural and professional background in mind, and be user-tested to avoid misunderstandings and diplomatic blunders (e.g., a thumbsup is a sign of approval in the US, but can be offensive in the Middle East). It is important that companion icons are relatively simple in shape and have a crisp outline so that they can be recognizable also in small-scale versions. 


\section{Examples}

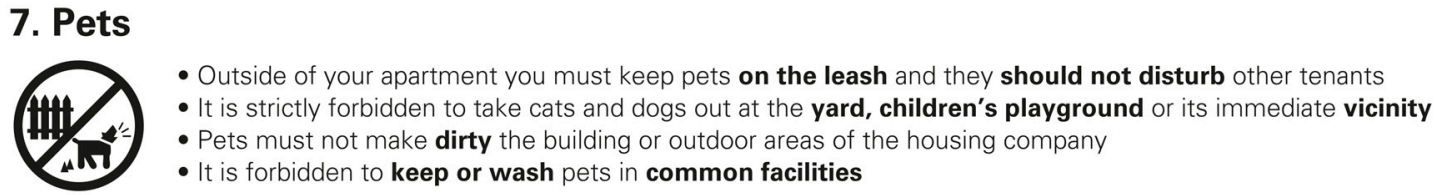

\section{Safety and prevention}

1. Use of dishwashers and washing machines

- The Tenant is responsible for the use, supervision and possible problems that occur with any equipment/machines that they or the previous tenant has installed

- Washing machines and dishwashers should always be installed by a professional

- The water supply tap must always be turned off after using the machine and a safety bin should be installed under the dish washer

- If a washing machine/dishwasher tap cannot be found in the apartment, it means that using one is not allowed

- In order to use washing machines and dishwashers the Tenant must have a home insurance

\section{Fire}

- When using doors which are to be kept locked, including fire doors, be sure that they remain locked after you for safety reasons

- It is forbidden to barbecue, light up torches or practise any other kind of activity on the balconies/terraces that may increase the risk of a fire

- Mopeds and similar items must not be stored in the basement/other indoor facilities unless fuel is completely drained

Figure 6.10: Excerpt from a prototype tenancy agreement for university students. The icons help to identify the contract topics more easily, and give a more friendly impression of the document (the readers are young, and for many of them this is the first tenancy agreement they sign).

\subsection{Delivery diagram pattern}

What is it - The delivery diagram is a technique to represent aspects of the terms of delivery of goods. It can indicate, for example, when and where delivery takes place and when the cost and risk are transferred.

When to use the pattern - Parties entering a contract for the sale and purchase of goods need to choose their terms for delivery. "Delivery" may mean many things, not only shipment or arrival, but also placing the goods onboard a carrier or other alternatives. The choices affect how the cost, risk, and responsibility for loading, unloading, customs duties, taxes, and other matters are divided between the parties. In order to avoid misunderstandings and simplify choice, the International Chamber of Commerce publishes Incoterms ${ }^{\circledR}$ rules, ${ }^{24}$ a set of trade terms widely used in international trade. However, there are a number of alternatives in the rules, so the parties need support in comparing them and making a choice.

\footnotetext{
24 "Incoterms" is a trademark of the International Chamber of Commerce (ICC).
} 
Rationale for using the pattern - The delivery diagram illustrates precisely what delivery means: where it happens, how, and in which moment in time and space various responsibilities pass. Delivery diagrams have been widely used in connection with the Incoterms ${ }^{\circledR}$ rules, in order to explain the various trade terms' essence in a simple way and allow comparison. A quick Google image search shows the popularity of the format: many versions of the diagrams can be found. The diagram can also be used to describe non-standard delivery terms, since its familiar format can be adapted flexibly to a variety of situations (Figure 6.11).

How to apply the pattern - The top part of the diagram presents, from left to right, representations of possible places of delivery: for example, at the supplier's premises, on board a carrier, at the departure shipping terminal, on board a vessel at the departure terminal, at the arrival terminal, or at the buyer's warehouse. If the goal of the diagram is to compare different delivery terms, many places of delivery will be included. If the diagram seeks to clarify one specific term, we recommend, for clarity's sake, including only the delivery place in question. Text labels can be added to provide more details about where the goods are actually delivered (e.g., if they need to be unloaded from the carrier and placed in a certain spot; Figure 6.11). Below these representations, there are usually color-coded lines (one color for the buyer, one for the supplier) which indicate the division and point of transfer of cost and risk (and possibly other obligations, e.g., to clear for customs or to insure). 


\section{Examples}

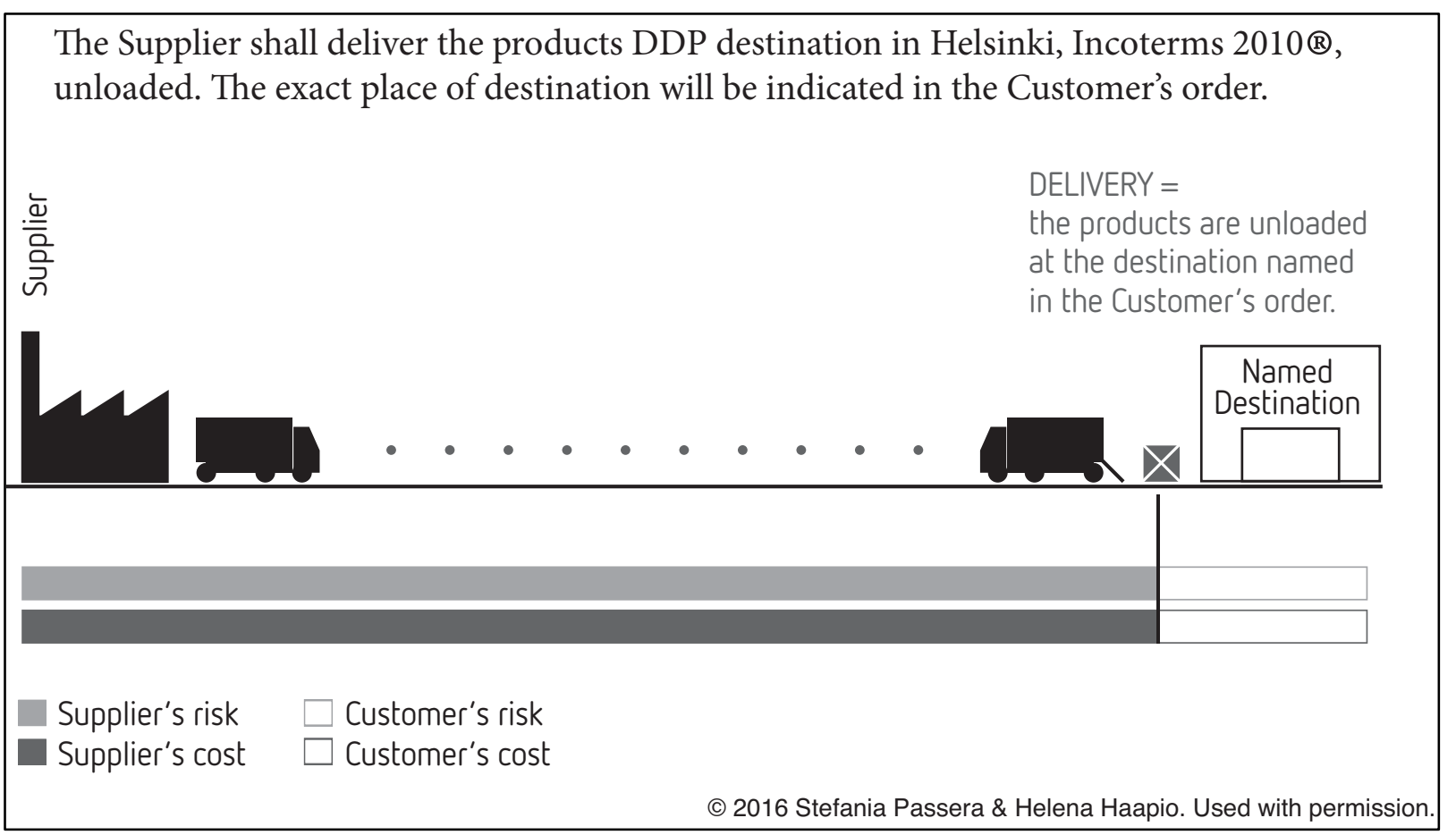

Figure 6.11: Example of a delivery chart in a Framework Agreement for the Purchase of Goods. The clause modifies the DDP (Delivered Duty Paid) trade term as included in the Incoterms ${ }^{\circledR} 2010$ rules by requiring the supplier to unload the goods at destination. The diagram seeks to underline this crucial difference and help avoid problems.

\section{Visualizations for contracts: how an image can save money and lead to better decisions}

In the previous section, we have shown how patterns can provide clarity at the implementation stage - in and about contracts. They can also be helpful PPL tools at the planning and negotiation stage. At times, the interests of the parties to a contract negotiation are widely misaligned. For instance, one party may wish to have a long-term commitment, while the other wishes to be able to walk away from the deal at short notice. In the following example from Canada, a termination clause was interpreted differently by the parties, and led to a less than amicable end to the contract.

In the Spring of 2002, Rogers Communications Inc., a Canadian telecom company, entered into a contract with Aliant Inc. (Bell Aliant) in which Aliant agreed to string Rogers' cable lines across roughly 91,000 utility poles for an annual fee of $\$ 9.60$ per pole. Early in 2005, Aliant informed Rogers that it was terminating the contract with one year's notice and increasing its 
rates. Rogers objected, on the grounds that the contract could not be terminated until the Spring of 2007.

It would have been best for the parties to have discovered their different views of the contract at the negotiations stage. But they did not. In this case, the misaligned expectations and lack of clarity lead to a million dollar, eighteen month dispute over the meaning of a single clause. The clause read as follows (Telecom Decision CRTC 2006-45; Telecom Decision CRTC 2007-75) ${ }^{25}$ :

This agreement shall be effective from the date it is made and shall continue in force for a period of five (5) years from the date it is made, and thereafter for successive five (5) year terms, unless and until terminated by one year prior notice in writing by either party.

This clause was interpreted differently by the two parties. As regards the initial term of the agreement, one party (Rogers) thought that it had a five-year deal. The other party (Aliant) believed that even within this initial term, the agreement could be terminated at any time with one year's notice. In hindsight, it is easy to say that the parties and their lawyers should have had a closer look at the clause before signing the agreement. In this case, neither party had a hand in crafting the text; it was imposed by Canadian telecom regulators. The drafters of the model form used in this case could have used clearer language. Breaking the clause into two sentences might have been a way to avoid the ambiguity. Yet sketching simple pictures, as in Figure 7.1 below, would have shown the parties their different interpretations. This would have allowed them, during the negotiations, to come to a mutual understanding - or to see that they had no deal and walk away. In the words of Louis M. Brown (1950, 3): "It usually costs less to avoid getting into trouble than to pay for getting out of trouble".

\footnotetext{
${ }^{25}$ For more details and references, see, e.g., Haapio \& Siedel 2013, 164-7.
} 
ROGERS' UNDERSTANDING:

The contract is valid for an initial period of 5 years. One year prior to the end of this period, either party can give one year's notice to terminate.

ALIANT'S UNDERSTANDING:

The 5-year contract can be terminated at any time with one year's notice.

C2011 Stefania Passera \& Helena Haapio. Used with permission.
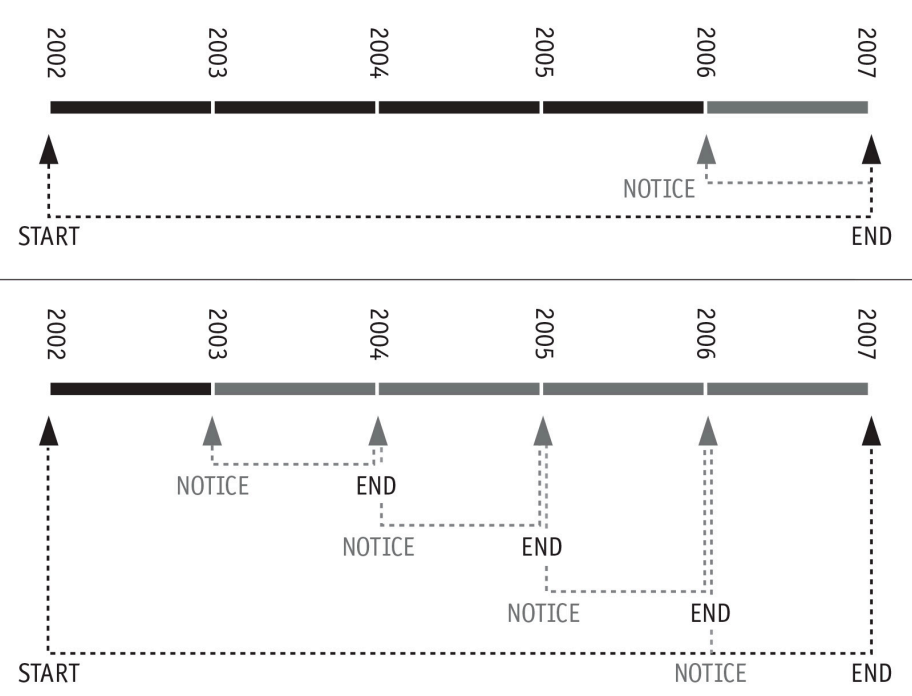

Figure 7.1: Two timelines that make different understandings visible (Passera \& Haapio, 2011).

Another example is provided by Siedel $(2016,177-8)$, who illustrates how decision trees help clarify negotiation decisions and depict the estimated costs and risks of alternatives. One application of decision trees is whether to retain, soften or eliminate controversial clauses which can result in long and expensive negotiations. For instance, insisting on negotiating a pricey indemnity for low-probability risks may in fact create a loss, since it requires management time to negotiate, and the lengthy negotiation delays profits. A decision tree (Figure 7.2) reveals the average expected value of alternative decisions, based on assumed values and event probabilities.

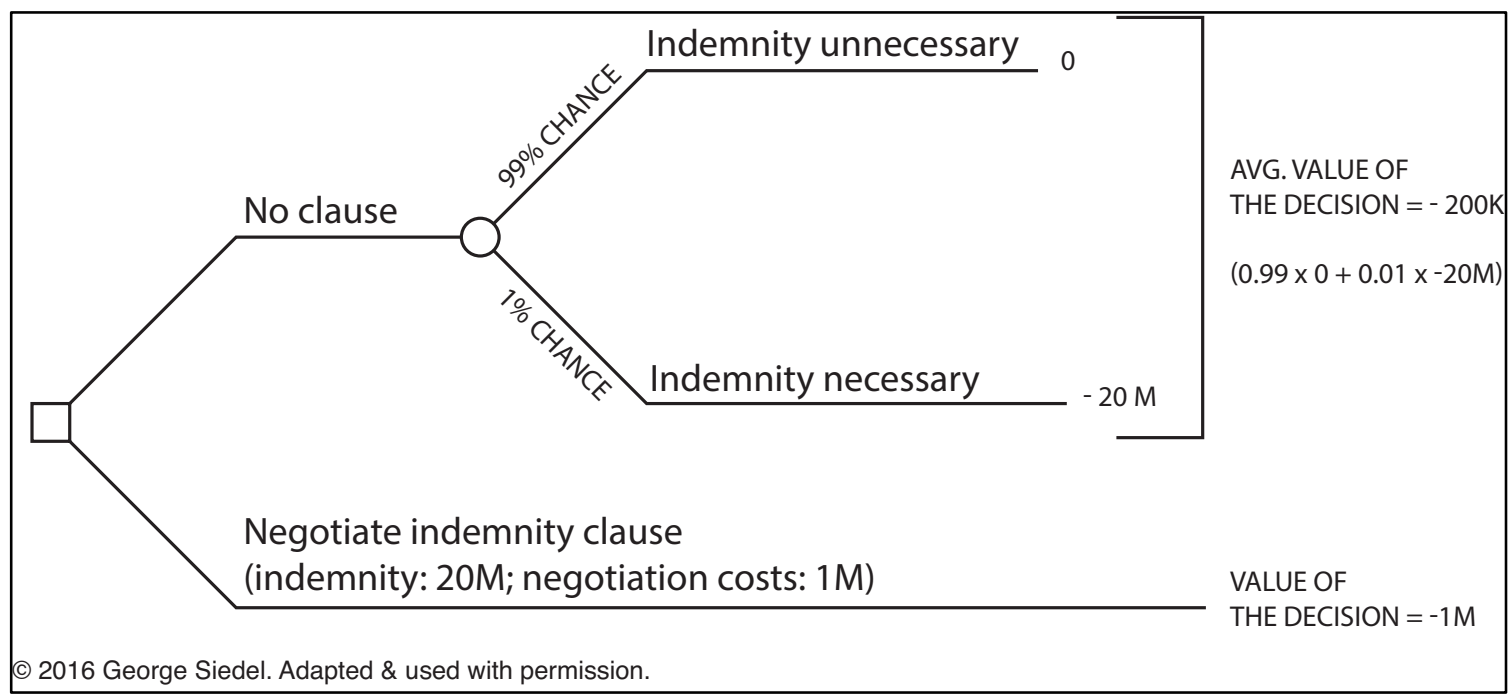

Figure 7.2: Decision tree to evaluate the average expected value of alternative decisions. In this case, the benefits of negotiating the clause are minimal $(200 \mathrm{~K})$ compared to the high costs incurred to negotiate it (1M). Adapted from Siedel, 2016, 177. 


\section{Conclusion}

PPL and information design share the same goal: empowering people and businesses to attain their goals. Both are centered on users' needs and oriented to results. When written and designed well, contracts can work as interfaces between businesses and functions, helping them reach the benefits of their collaboration. This chapter illustrates how contract design in general and design patterns in particular can provide repeatable and flexible best practice solutions to current contracting challenges. These solutions can contribute to the transformation of contracts from dysfunctional legal documents to functional communication tools that are both useful and usable for business. This chapter reviews and categorizes contract visualization patterns and explores the communicative solutions offered by visual representations. As illustrated through several examples, visual representations play a functional and explanatory role, remedying many of the typical shortcomings of contract text.

A pattern approach enables practitioners and researchers alike to identify and share effective solutions for planning, negotiating, and communicating contracts. Patterns offer flexibility in contract design: unlike rigid formalized rules, patterns can be mixed, modified, and adapted to fit specific contracting situations and user needs. The goal is to design contracts that work as effective interfaces, not only between businesses and functions, but also between individuals and the information they require to successfully do their job.

Confronted by evidence showing that the parties' perception of their agreement may vary greatly from the terms that appear in their contracts (e.g., Bix, 2013; Macaulay, 2003) and that most business people find contracts hard or impossible to read (IACCM, 2015a; 2015b), we believe that it is time for change. When contract design succeeds, contracts can reach their full potential: matching the parties' business needs, reflecting their true goals, and supporting implementation. By meeting users' needs, well-designed contracts can contribute to maintaining sustainable, successful business deals and relationships, and preventing unnecessary problems.

\section{References}

About the Contracts Wiki (n.d.) The Harvard Law School Contracts Wiki, ackwiki.com/drupal/about. Adams, K. (2008). Dysfunctional Drafting. National Law Journal, September 8. 
Adams, K. A. \& Allen, T. (2012). The Illusion of Quality in Contract Drafting. New York Law Journal, Vol. 248, No. 11, July 17. www.koncision.com/wp-content/uploads/2012/07/Illusion-of-Quality-NYLJ.pdf.

Alexander, C. (1979). The Timeless Way of Building, Vol. 1. New York: Oxford University Press.

Alexander, C., Ishikawa, S., Silverstein, M., Jacobson, M., Fiksdahl-King, I. \& Angel, S. (1977). A Pattern

Language - Towns, Buildings, Construction. New York: Oxford University Press.

Argyres, N. \& Mayer, K. J. (2007). Contract Design as a Firm Capability: An Integration of Learning and Transaction Cost Perspectives. Academy of Management Review, Vol. 32, No. 4, 1060-77.

Australian Office of Parliamentary Counsel (2013, December 19). Plain English Manual. www.opc.gov.au/about/docs/Plain_English.pdf.

Barton, T. D. (2007). Three Modes of Legal Problem Solving - and What to Do About Them in Legal Education. California Western Law Review, Vol. 43, 389-416. works.bepress.com/thomas_barton/10/.

Barton T. D. (2012). Collaborative Contracting as Preventive/Proactive Law. In: G. Berger-Walliser \& K. Østergaard, eds., Proactive Law in a Business Environment. Copenhagen: DJOF Publishing, 107-27.

Berman, D. (2000). Toward a New Format for Canadian Legislation - Using Graphic Design Principles and Methods to Improve Public Access to the Law. Human Resources Development Canada and Justice Canada. www.davidberman.com/NewFormatForCanadianLegislation.pdf.

Bix, B. H. (2013). The Role of Contract: Stewart Macaulay's Lessons from Practice. In: J. Braucher, J. Kidwell \& W. Whitford, eds., Revisiting the Contracts Scholarship of Stewart Macaulay: On the Empirical and the Lyrical. Oxford: Hart Publishing, 241-55. ssrn.com/abstract=2793543.

Brown, L. M. (1950). Preventive Law. New York, NY: Prentice-Hall, Inc.

Butterick, M. (2015). Typography for Lawyers. 2nd ed., Houston, TX: O’Connors.

Conboy, K. (2014). Diagramming Transactions: Some Modest Proposals and a Few Suggested Rules, Transactions: Tennessee Journal of Business Law, Vol. 16, 91-108.

Fuller, L. L. (1981). The Lawyer as an Architect of Social Structures. In: K. I. Winston, ed., The Principles of Social Order: Selected Essays of Lon L. Fuller. Durham, NC: Duke University Press, 264-70.

Gerding, E. F. (2013). Contract as Pattern Language. Washington Law Review, Vol. 88, No. 4, 1323-56. ssrn.com/abstract $=2371097$.

Gibson, J. J. (1977). The theory of affordances. In: R. Shaw \& J. Bransford, eds., Perceiving, Acting, and Knowing. Hillsdale, NJ: Lawrence Erlbaum Associates.

Haapio, H. (2013a) Good Contracts: Bringing Design Thinking into Contract Design. In: J. Chittenden, ed., Proceedings of the 2013 IACCM Academic Forum. Ridgefield, CT: International Association for Contract and Commercial Management, 95-136. www.iaccm.com/resources/?id=4958.

Haapio, H. (2013b). Next Generation Contracts: A Paradigm Shift. Helsinki: Lexpert Ltd.

Haapio, H. (2014a). Lawyers as Designers, Engineers and Innovators: Better Legal Documents through Information Design and Visualization. In: E. Schweighofer, F. Kummer \& W. Hötzendorfer, eds., Transparency. Proceedings of the 17th International Legal Informatics Symposium IRIS 2014. Wien: Österreichische Computer Gesellschaft OCG, 451-8.

Haapio, H. (2014b). Using the CISG Proactively. In: L. A. DiMatteo, ed., International Sales Law: A Global Challenge. New York, NY: Cambridge University Press, 704-23.

Haapio, H. (2016). Contract Design Manifesto. Proposal accepted for presentation at the IACCM Academic Forum, San Diego, 24 October 2016. 
Haapio, H. \& Barton, T. (forthcoming). Business-Friendly Contracting: How Simplification and Visualization Can Help Bring It to Practice. In: K. Jacob, D. Schindler \& R. Strathausen, eds., Liquid Legal: Transforming Legal into a Business Savvy, Information Enabled and Performance Driven Industry. Springer International

Haapio, H. \& Haavisto, V. (2005). Sopimusosaaminen: tulevaisuuden kilpailutekijä ja strateginen voimavara. [Contracting Capabilities: Emerging Source of Competitive Advantage and a Strategic Resource]. Yritystalous Leader's Magazine, No. 2, 7-15.

Haapio, H. \& Hagan, M. (2016). Design Patterns for Contracts. In: E. Schweighofer, F. Kummer, W. Hötzendorfer \& G. Borges, eds., Networks. Proceedings of the 19th International Legal Informatics Symposium IRIS 2016. Wien: Österreichische Computer Gesellschaft OCG/books@ocg.at, 381-8.

Haapio, H. \& Passera, S. (2013). Visual Law: What Lawyers Need to Learn from Information Designers. VoxPopuLII Blog post, May 15. Cornell University Law School. blog.law.cornell.edu/voxpop/2013/05/15/visuallaw-what-lawyers-need-to-learn-from-information-designers/.

Haapio, H., Plewe, D. A. \& de Rooy, R, (2016). Next Generation Deal Design: Comics and Visual Platforms for Contracting. In: E. Schweighofer, F. Kummer, W. Hötzendorfer \& G. Borges, eds., Networks. Proceedings of the 19th International Legal Informatics Symposium IRIS 2016. Wien: Österreichische Computer Gesellschaft OCG/books@ocg.at, 373-80.

Haapio, H. \& Siedel, G. J. (2013). A Short Guide to Contract Risk. Farnham: Gower.

Howarth, D. (2013). Law as Engineering: Thinking about What Lawyers Do. Cheltenham: Edward Elgar Publishing Limited.

IACCM (2015a). Attitudes to Contracting. Ridgefield, CT: International Association for Contract and Commercial Management. www2.iaccm.com/resources/?id=8440 and s3.eu-central-

1.amazonaws.com/iaccmportal/files/8440_iaccmresearchreportattitudestocontractingsurvey2013.pdf.

IACCM (2015b). Commercial Excellence: Ten Pitfalls to Avoid in Contracting. Ridgefield, CT: International Association for Contract and Commercial Management. info.iaccm.com/commercial-excellence-ten-pitfalls-toavoid-in-contracting.

IACCM (2015c). Top Negotiated Terms 2015: No News Is Bad News. International Association for Contract and Commercial Management IACCM. www2.iaccm.com/resources/?id=8930.

IACCM (2016). Contract Design Assessment. www.iaccm.com/contract-design-assessment.

International Chamber of Commerce ICC (2010). Incoterms ${ }^{\circledR} 2010$ Wallchart. ICC publication No. 716E.

ISO 5807:1985. Information Processing. Documentation Symbols and Conventions for Data, Program and System Flowcharts, Program Network Charts and System Resources Charts.

Jacobson, S. (2008). A Checklist for Drafting Good Contracts. Journal of the Association of Legal Writing Directors, Vol. 5, Fall, 79-117. ssrn.com/abstract=1268448.

Jones, H. W. \& Oswald, M. (2001). Doing Deals with Flowcharts. ACCA Docket, Vol.19, No. 9, October, 94-108.

JYSEn käyttämisopas. JYSE 2009 PALVELUT. (Julkisten hankintojen yleiset sopimusehdot palveluhankinnoissa 21.10.2010) (2013). Aalto University/SimLab \& Association of Finnish Local and Regional Authorities. goo.gl/MXx6u5.

Keating, A. \& Andersen, C. (forthcoming). A Graphic Contract - Taking Visualisation in Contracting a Step Further. Journal of Strategic Contracting and Negotiation

Khambete, P. (2011). A Pattern Language for Touch Point Ecosystem User Experience: A Proposal. In: Proceedings of the 3rd International Conference on Human Computer Interaction (IndiaHCI '11). New York, NY: Association for Computing Machinery, 68-74. doi.acm.org/10.1145/2407796.2407805. 
Kimble, J. (2002). The Elements of Plain Language. Michigan Bar Journal, Vol. 81, No. 10, 44-5.

Kobayashi, B. H. \& Ribstein, L. E. (2011). Law's Information Revolution. Arizona Law Review, Vol. 53, Issue 4, 1169-220. www.arizonalawreview.org/pdf/53-4/53arizlrev1169.pdf.

Koskinen, K. U. \& Mäkinen, S. (2009). Role of Boundary Objects in Negotiations of Project Contracts. International Journal of Project Management, Vol. 27, No. 1, 31-8.

Lengler, R. \& Eppler, M. J. (2007). Towards a Periodic Table of Visualization Methods of Management. In: Proceedings of the IASTED International Conference on Graphics and Visualization in Engineering, GVE '07, Anaheim, CA: ACTA Press, 83-8. dl.acm.org/citation.cfm?id=1712936.1712954.

Macaulay, S. (2003). The Real and the Paper Deal: Empirical Pictures of Relationships, Complexity and the Urge for Transparent Simple Rules. The Modern Law Review, Vol. 66, No. 1, 44-79. doi:10.1111/1468-2230.6601003. www.law.wisc.edu/facstaff/macaulay/papers/real_paper.pdf.

Macneal, I. \& Gudel, P. (2001). Contracts: Exchange Transactions and Relations. New York, NY: Foundation Press.

Mahler, T. (2013). A Graphical User-Interface for Legal Texts? In: D. J. B. Svantesson \& S. Greenstein, eds., Internationalisation of Law in the Digital Information Society. Nordic Yearbook of Law and Informatics 2010-2012. Copenhagen: Ex Tuto Publishing, 311-27.

Malhotra, D. (2012). Great Deal, Terrible Contract: The Case for Negotiator Involvement in the Contracting Phase. In: B. M. Goldman \& D. L. Shapiro, eds., The Psychology of Negotiations in the 21st Century Workplace. New Challenges and New Solutions. New York, NY: Routledge, 363-398.

Mamula, T. \& Hagel, U. (2015). The Design of Commercial Conditions - Layout, Visualization, Language. In: E. Schweighofer, F. Kummer, W. Hötzendorfer, eds., Co-operation. Proceedings of the 18th International Legal Informatics Symposium IRIS 2015. Wien: Österreichische Computer Gesellschaft OCG, 471-8.

Meirelles, I. (2013). Design for Information: An Introduction to the Histories, Theories, and Best Practices Behind Effective Information Visualizations. Beverly, MA: Rockport Publishers.

Mellinkoff, D. (1982). Legal Writing: Sense \& Nonsense. St. Paul, MN: West Publishing.

Michael, D. \& Hartley, J. (1991). Extracting Information from Flowcharts and Contingency Statements: The Effects of Age and Practice. British Journal of Educational Technology, Vol. 22, No. 2, 84-98.

Mitchell, J. A. (2015). Putting Some Product into Work-Product: Corporate Lawyers Learning from Designers. Berkeley Business Law Journal, Vol. 12, Issue 1, 1-44. scholarship.law.berkeley.edu/bblj/vol12/iss 1/1/.

NEC (2013a). NEC3 Engineering and Construction Contract Flow Charts. London: Thomas Telford.

NEC (2013b). NEC3 Professional Services Contract Guidance Notes and Flow Charts. London: Thomas Telford.

Norman, D. A. (2013). The Design of Everyday Things. Revised and expanded edition. New York, NY: Basic Books.

Orna, E. (2005). Making Knowledge Visible. Communicationg Knowledge Through Information Products. Aldershot: Gower Publishing.

Pan, Y. \& Stolterman, E. (2013). Pattern Language and HCI: Expectations and Experiences. In: CHI 2013 Extended Abstracts on Human Factors in Computing Systems. New York, NY: Association of Computing Machinery, 198998.

Passera, S. (2015). Beyond the Wall of Text: How Information Design Can Make Contracts User-Friendly. In: A. Marcus, ed., Design, User Experience, and Usability: Users and Interactions. Lecture Notes in Computer Science. Springer International Publishing, 341-52. 
Passera, S. \& Haapio, H. (2011). Facilitating Collaboration through Contract Visualization and Modularization. In: Proceedings of the 29th Annual European Conference on Cognitive Ergonomics (ECCE '11). New York, NY: Association of Computing Machinery, 57-60. dx.doi.org/10.1145/2074712.2074724.

Passera, S. \& Haapio, H. (2013). Transforming Contracts from Legal Rules to User-centered Communication Tools: A Human-information Interaction Challenge. Communication Design Quarterly, Vol. 1, Issue 3 (April), 38-45. sigdoc.acm.org/wp-content/uploads/2012/09/CDQ-April-1-3-FINAL.pdf.

Passera, S., Haapio, H., Waller, R., Tomlinson, O., Edwards, C., Zarcate, O., Arellano, G. \& Mariani, J. (2013). Visual CISG - A Prototype of Legal Information Design. Draft, 10.10.2013. CISG Legal Design Jam Group @ Syros 2013. legaldesignjam.com/wp-content/uploads/2016/03/visualCISG_booklet.pdf.

Passera, S., Kankaanranta, A., \& Louhiala-Salminen, L. (forthcoming). Diagrams in Contracts: Fostering Understanding in Global Business Communication. IEEE Transactions on Professional Communication.

Passera, S., Pohjonen, S., Koskelainen, K. \& Anttila, S. (2013). User-Friendly Contracting Tools - A Visual Guide to Facilitate Public Procurement Contracting. In: J. Chittenden, ed., Proceedings of the 2013 IACCM Academic Forum for Integrating Law and Contract Management: Proactive, Preventive and Strategic Approaches. Ridgefield, CT: The International Association for Contract and Commercial Management, 74-94.

Passera, S., Smedlund, A. \& Liinasuo, M. (forthcoming). Exploring Contract Visualization: Clarification and Framing Strategies to Shape Collaborative Business Relationships. Journal of Strategic Contracting and Negotiation.

Plain Language Action and Information Network (2011, May 1). Federal Plain Language Guidelines. Revision 1. www.plainlanguage.gov/howto/guidelines/FederalPLGuidelines/FederalPLGuidelines.pdf.

Plewe, D. (2013). A Visual Interface for Deal Making. In: M. J. O’Grady et al., eds., Evolving Ambient Intelligence - AmI 2013 Workshops, Dublin, Ireland, December 3-5, 2013. Revised Selected Papers. Communications in Computer and Information Science Series, Vol. 413, Springer International Publishing, 205-12.

Plewe, D. A. \& de Rooy, R. (forthcoming). Integrative Deal-Design: Cascading from Goal-hierarchies to Negotiations and Contracting. Journal of Strategic Contracting and Negotiation.

Scaife, M. \& Rogers, Y. (1996). External Cognition: How Do Graphical Representations Work? International Journal of Human-Computer Studies, Vol. 45, No. 2, 185-213.

Schepker, D. J., Oh, W.-Y., Martynov, A. \& Poppo, L. (2014). The Many Futures of Contracts Moving Beyond Structure and Safeguarding to Coordination and Adaptation. Journal of Management, Vol. 40, No. 1, $193-225$.

Siedel, G. (2016). The Three Pillar Model for Business Decisions: Strategy, Law \& Ethics. Ann Arbor, MI: Van Rye Publishing.

Sless, D. (2015). Regulating Information for People: How Information Design Has Made A Difference in the Ways in Which Governments and Industry Regulate Information. In: J. Frascara, ed., Information Design as Principled Action: Making Information Accessible, Relevant, Understandable, and Usable. Champaign, IL: Common Ground Publishing LLC, 190-209.

Stenning, K. \& Oberlander, J. (1995). A Cognitive Theory of Graphical and Linguistic Reasoning: Logic and Implementation. Cognitive Science, Vol. 19, No. 1, 97-140.

Strylowski, J. (2013). Using Tables to Present Complex Ideas. Michigan Bar Journal, Vol. 92, No. 2, 44-7.

System Shocks and Collaborative Contract Innovation (n.d.) The Harvard Law School Contracts Wiki. ackwiki.com/drupal/.

Telecom Decision CRTC 2006-45. Ottawa, 28 July. www.crtc.gc.ca/eng/archive/2006/dt2006-45.htm.

Telecom Decision CRTC 2007-75. Ottawa, 20 August. www.crtc.gc.ca/eng/archive/2007/dt2007-75.htm. 
Tidwell, J. (2014). Designing Interfaces. 2nd ed., Sebastopol, CA: O’Reilly Media.

Tsygankova, T. (2016). Design for Good Commercial Contracts - Practical Tools for Contract Drafters. In: E. Schweighofer, F. Kummer, W. Hötzendorfer \& G. Borges, eds., Networks. Proceedings of the 19th International Legal Informatics Symposium IRIS 2016. Wien: Österreichische Computer Gesellschaft OCG/books@ocg.at, 40714.

Waller R. (2012). Graphic Literacies for a Digital Age: The Survival of Layout, The Information Society, Vol. 28, No. 4, 236-52.

Waller, R. \& Delin, J. (2011). Towards a Patterns Language Approach to Document Description. Simplification Center Technical paper 4, April 2011. www.reading.ac.uk/web/FILES/simplification/tech_paper_4.pdf. Waller, R., Waller, J., Haapio, H., Crag, G., \& Morrisseau, S. (forthcoming). Cooperation Through Clarity: Designing Simplified Contracts. Journal of Strategic Contracting and Negotiation.

Weber, L., \& Mayer, K. J. (2011). Designing Effective Contracts: Exploring the Influence of Framing and Expectations. Academy of Management Review, Vol. 36, No. 1, 53-75.

Williams, C. (2011). Legal English and Plain Language: An Update. ESP Across Cultures, Vol. 8, $139-51$.

Yahoo (n.d.). Yahoo Design Pattern Library. developer.yahoo.com/ypatterns/. 